\title{
CILVĒKA RESPIRATORĀ SINCITIĀLĀ VĪRUSA IZRAISĪTO DZIĻĀKO ELPCEĻU INFEKCIJU KLĪNISKAIS UN MOLEKULĀRAIS RAKSTUROJUMS HOSPITALIZĒTIEM BĒRNIEM LATVIJĀ
}

Promocijas darba kopsavilkums medicīnas doktora zinātniskā grāda iegūšanai Specialitāte - pediatrija 


\section{RĪGAS STRADIN̦A \\ UNIVERSITĀTE}

Reinis Balmaks

\section{CILVĒKA RESPIRATORĀ SINCITIĀLĀ VĪRUSA IZRAISĪTO DZIL̨ĀKO ELPCEL,U INFEKCIJU KLINNISKAIS UN MOLEKULĀRAIS RAKSTUROJUMS HOSPITALIZĒTIEM BĒRNIEM LATVIJĀ}

Promocijas darba kopsavilkums medicīnas doktora zinātniskā grāda iegūšanai

Specialitāte - pediatrija

Rīga, 2014 
Promocijas darbs izstrādāts:

Rīgas Stradiña universitātes Pediatrijas katedrā

Latvijas Biomedicīnas pētîjumu un studiju centrā

Darba zinātniskie vadītāji:

Dr. habil. med., profesore Dace Gardovska,

RSU Pediatrijas katedra

Dr. biol. Andris Kazāks,

Latvijas Biomedicīnas pētîjumu un studiju centrs

Oficiālie recenzenti:

Dr. biol., asociētais profesors Edvīns Miklašēvics,

RSU Onkologijas institūts

Dr. med., asociētais profesors Enoks Biķis,

Latvijas Universitātes Medicīnas fakultāte, Pediatrijas katedra

Ph. D., docents Matti Waris,

Turku Universitātes Virusologijas katedra

Promocijas darba aizstāvēšana notiks 2014. gada 11. martā plkst. 15.00 Rīgas Stradiņa universitātes Medicīnas promocijas padomes atklātā sēdē Rīgā, Dzirciema ielā 16, Hipokrāta auditorijā

Ar promocijas darbu var iepazīties RSU bibliotēkā un RSU mājas lapā: www.rsu.lv

Promocijas darbs izstrādāts ar ESF līdzfinansēta projekta „Atbalsts doktorantiem studiju programmas apguvei un zinātniskā grāda ieguvei Rīgas Stradiña universitātē”, vienošanās Nr. 2009/0147/1DP/1.1.2.1.2/09/IPIA/VIAA/009, atbalstu

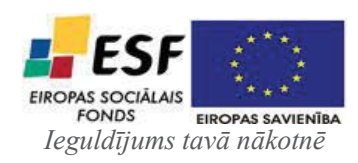

Promocijas padomes sekretāre:

Dr. med., asociētā profesore Angelika Krūmiṇa 


\section{SATURS}

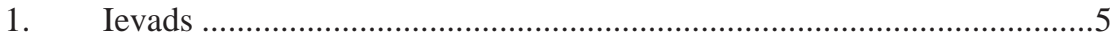

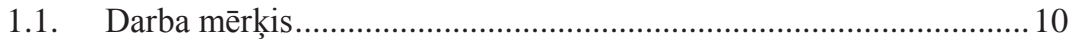

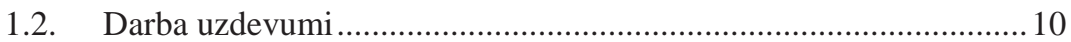

1.3. Darba hipotēzes ............................................................................ 10

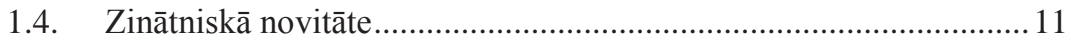

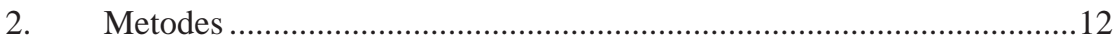

2.1. Pētījuma populācija........................................................................ 12

2.2. Klīniskie paraugi.......................................................................... 12

2.3. HRSV diagnostika, grupu diferencēšana, sekvenēšana ...................13

2.4. Filoğenēzes un adaptīvās evolūcijas analīze .....................................14

2.5. Evolūcijas ātrums, populācijas dinamika un filogigeogrāfiskā

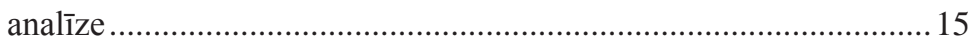

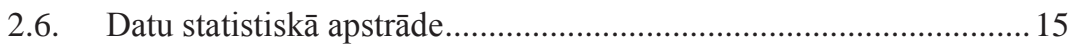

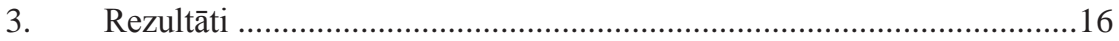

3.1. Pētījuma pamatgrupa ..................................................................... 16

3.2. HRSV diagnostika un grupu diferencēšana ....................................16

3.3. HRSV sezonalitāte...................................................................... 17

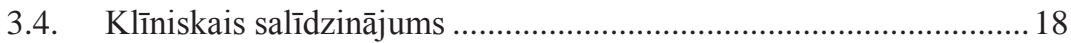

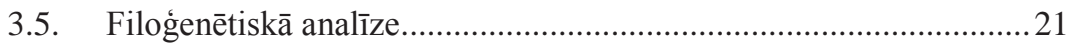

3.6. Genotipa NA1 molekulārais raksturojums........................................ 24

3.7. Genotipa BA-IV molekulārais raksturojums .................................. 25

3.8. Genotipa ON1 globālā filodinamika un filogieogrāfija .................... 26

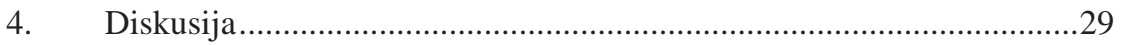

4.1. Pētījuma pamatgrupa …...............................................................29

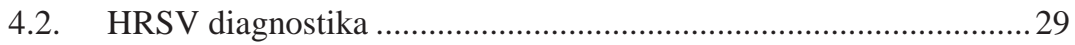

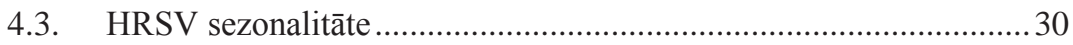

4.4. HRSV klīnisko pazìmju raksturojums .............................................. 31 
4.5. HRSV grupu un genotipu klīniskais salīdzinājums .......................... 32

4.6. HRSV celmu molekulārā analīze .................................................... 33

4.7. HRSV celmu globālā diseminācija.................................................. 37

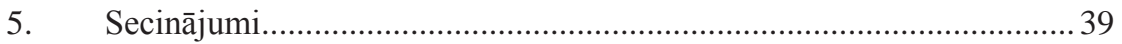

6. Praktiskās rekomendācijas .................................................................. 40

7. Autora publikācijas .................................................................................... 41

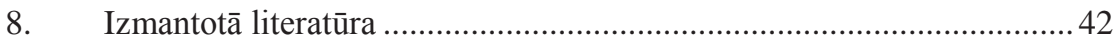




\section{DARBĀ LIETOTIE SAĪSINĀJUMI}

\begin{tabular}{|c|c|}
\hline Apzīmējums & Skaidrojums \\
\hline 95\% HPD & 95\% augstākās varbūtības blīvums \\
\hline аa & Aminoskābe(s) \\
\hline BKUS & $\begin{array}{l}\text { Valsts sabiedrības ar ierobežotu atbildību „Bērnu klīniskā } \\
\text { universitātes slimnīca” Torņakalna novietne }\end{array}$ \\
\hline bp & Bāžu pāri \\
\hline BSP & Baijesa apvāršņa grafiks \\
\hline cDNS & Komplementārā DNS \\
\hline$d N$ & $\begin{array}{l}\text { Ne-sinonīma mutācija - kodējošās sekvences nukleotīda } \\
\text { nomaiṇa, kuras rezultātā aminoskābju sekvence mainās }\end{array}$ \\
\hline$d N / d S$ & Ne-sinonīmo/sinonīmo mutāciju attiecība \\
\hline DNS & Dezoksiribonukleīnskābe \\
\hline$d S$ & $\begin{array}{l}\text { Sinonīma mutācija - kodējošās sekvences nukleotīda nomaiņa, } \\
\text { kuras rezultātā nemainās aminoskābju sekvence }\end{array}$ \\
\hline FEL & $\begin{array}{l}\text { Nemainīgas ietekmes paticamības metode selekcijas spiediena } \\
\text { noteikšanai }\end{array}$ \\
\hline $\mathrm{Fr}$ & $\begin{array}{l}\text { Francijas kateteru skalas mērvienība (1 Fr katetram ir } 1 / 3 \mathrm{~mm} \\
\text { diametrs) }\end{array}$ \\
\hline HRSV & Cilvēka respiratorais sincitiālais vīruss \\
\hline HRSV-A & $\begin{array}{l}\text { A grupas cilvēka respiratorais sincitiālais vīruss, viena no } \\
\text { divām galvenajām antigēnajām grupām }\end{array}$ \\
\hline HRSV-B & $\begin{array}{l}\text { B grupas cilvēka respiratorais sincitiālais vīruss, viena no } \\
\text { divām galvenajām antigēnajām grupām }\end{array}$ \\
\hline HVR & Hipervariablais regions \\
\hline IFA & Imūnfluorescences tests \\
\hline IFEL & $\begin{array}{l}\text { Iekšejjās nemainīgās ietekmes paticamības metode selekcijas } \\
\text { spiediena noteikšanai }\end{array}$ \\
\hline IV & Intravenozs(i) \\
\hline $\mathrm{kB}$ & Kilobāze(s); 1000 bāžu pāri \\
\hline KSS & Klīniskā smaguma skala \\
\hline LIC & $\begin{array}{l}\text { SIA „Rīgas Austrumu klīniskā universitātes slimnīca” } \\
\text { stacionārs „Latvijas Infektologijas centrs” }\end{array}$ \\
\hline MCC & Maksimālās radniecības ticamības filoǵenētiskais koks \\
\hline MCMC & Markova ķēdes Montekarlo algoritms \\
\hline MEME & $\begin{array}{l}\text { Dažādu ietekmju molekulārās evolūcijas metode selekcijas } \\
\text { spiediena noteikšanai }\end{array}$ \\
\hline ML & Maksimālās paticamības metode \\
\hline $\mathrm{Ne}$ & Efektīvās populācijas izmērs \\
\hline NFA & Nazofaringeālais aspirāts \\
\hline
\end{tabular}


NJ

nt

PCR

pmol

PVO

RDNI

REL

RNS

RT-PCR

SD

SIRS

SLAC

SPKC

ssRNS

tMRCA

$\pi$

$\tau$
Neighbor-joining ātrās klasterizācijas algoritms

Nukleotīds(i)

Polimerāzes k̦ēdes reakcija

Pikomols

Pasaules Veselības organizācija

Respiratorā distresa novērtēšanas instruments

Nejaušas ietekmes paticamības metode selekcijas spiediena noteikšanai

Ribonukleīnskābe

Apgrieztās (reversās) transkripcijas PCR

Standartnovirze

Sistēmiska iekaisuma atbildes sindroms

Vienas paticamības ciltstēvu skaitīšanas metode selekcijas spiediena noteikšanai

Slimību profilakses un kontroles centrs

Vienpavediena RNS

Kopīgā ciltstēva laiks

Nukleotīdu polimorfisms (vidējais nukleotīdu nomaiņu skaits novietojumā)

Paaudzes ilgumu gados 


\section{IEVADS}

Cilvēka respiratorais sincitiālais vīruss $\left(\mathrm{HRSV}^{1}\right)$ ir visbiežākais dziḷāko elpceḷu infekciju izraisītājs agrīna vecuma bērniem, kas šajā grupā ir vadošais mirstības un hospitalizācijas iemesls. Pēc epidemiologiskiem aprēķiniem HRSV katru gadu pasaulē izraisa aptuveni 33,8 miljonus jaunas infekcijas bērniem vecumā līdz pieciem gadiem [Nair et al., 2010]. Apmēram 10\% inficēto bērnu attīstās smaga dziḷāko elpceļu infekcija, kuriem nepieciešama hospitalizācija, un kopējā ikgadējā mirstība šajā vecumā tiek lēsta ap 234000 [Lozano et al., 2012]. Attīstītajās valstīs tā ikgadējie uzliesmojumi ir vairāk saistīti ar milzīgu slogu veselības budžetam. Līdz gada vecumam ar HRSV inficējas aptuveni $70 \%$ bērnu, bet līdz divu gadu vecumam - vairāk kā 90\% [Glezen et al., 1986; Simões and Carbonell-Estrany, 2003]. HRSV konstatē aptuveni $45 \%$ no hospitalizētiem bērniem ar dziḷāko elpceḷu infekciju, kas jaunāki par diviem gadiem [Simões and Carbonell-Estrany, 2003]. Vissmagāk slimība noris un vislielākā mirstība sastopama bērniem ar pavadošām slimībām, galvenokārt neiznestību, hemodinamiski nozīmīgu iedzimtu sirdskaiti un hronisku plaušu slimību (saistībā ar neiznestību, cistiskā fibroze u.c.) [Shay et al., 2001]. Pēdējos gados ir apzināta arī liela morbiditāte un mortalitāte augsta riska pieaugušo un vecu l̦aužu populācijās, kur mirstība ir pat lielāka kā bērnu populācijā [Falsey et al., 2005]. Lai arī HRSV ir tikai viens serotips, pēc infekcijas neizveidojas pasargājoša imunitāte, tāpēc dzīves un pat vienas sezonas laikā ir iespējams inficēties atkārtoti [Henderson et al., 1979; Simões and Carbonell-Estrany, 2003]. Latvijā HRSV epidemiologiskās uzraudzības dati ir skopi. Ir zināms, ka HRSV īpatsvars starp pārbaudītajiem respiratorajiem vīrusiem Latvijā pēdējos gados ir bijis no 15-47\% [Nikiforova et al., 2011], bet incidences, mirstības un sezonalitātes dati nav zināmi.

\footnotetext{
${ }^{1}$ Human respiratory syncytial virus.
} 
HRSV ierobežošanā un ārstēšanā ir vairākas problēmas. Elpošanas atbalsts un hidratācija joprojām ir terapijas stūrakmeņi [American Academy of Pediatrics, Subcommittee on Diagnosis and Management of Bronchiolitis, 2006;]. Citi pētītie līdzekḷi (t.sk. antivirālie) randomizētos kontrolētos pētījumos ir uzrādījuši limitētu efektu. Bērnu mirstības samazināšanās no HRSV infekcijas attīstītajās valstīs ir galvenokārt saistīta ar vispārīgu intensīvās terapijas attīstību. Lai arī ir pieejama efektīva pasīvā imūnprofilakse ar monoklonālo antivielu palivizumabu, tomēr šī preparāta nelabvēlīgā izmaksuieguvumu attiecība ierobežo pielietošanu plašai populācijai [American Academy of Pediatrics Committee on Infectious Diseases, 2009]. Vakcīna ir medicīniska nepieciešamība un būtu ekonomiski izdevīga [Meijboom et al., 2012], bet tās izstrāde kavējas I fāzes klīniskajos pētījumos [Anderson et al., 2013]. Šo uzdevumu būtiski apgrūtina HRSV lielā g̊enētiskā main̄̄ba.

HRSV ir klasificêts Pneumovirus ǵintī, Pneumovirinae apakšdzimtā, Paramyxoviridae dzimtā. Tas ir apvalkots vīruss ar vienas molekulas, lineāru, vienpavediena RNS genomu [Wang et al., 2012]. HRSV virālā RNS ir aptuveni 15,2 kB gara un tās 10 gēni kodē 11 proteīnus [Collins and Crowe, 2007], no kuriem divi virsmas glikoproteīni, G un F, ir imunologiski nozīmīgi, jo izsauc neitralizējošo antivielu atbildi. Pēc reakcijas ar monoklonālajām antivielām, HRSV celmi tiek iedalīti divās galvenajās grupās, HRSV-A un HRSV-B [Mufson et al., 1985], kas atbilst ǵenētiski atšķirīgiem vīrusiem [Zlateva et al., 2005]. Epidēmiskajās sezonās abas HRSV grupas cirkulē paralēli, bet ar mainīgu prevalenci. Parasti vērojama cikliska dominantās grupas maiņa, kur pēc vairākām secīgām HRSV-A dominantām sezonām seko viena HRSV-B dominanta sezona [Venter et al., 2001; Zlateva et al., 2007]. Ievērojama HRSV mainība ir vērojama arī grupu ietvaros, un abās grupās cirkulējošie celmi tiek iedalīti vairākos genotipos. Vienlaicīgi sabiedrībā var cirkulēt dažādi genotipi, kurus sekojošās sezonās var nomainīt jauni, savukārt, iepriekš izplatīti genotipi 
izzust [Peret et al., 2000; Venter et al., 2001; Zlateva et al., 2007]. Vislielākās atšķirības gan starp abām grupām, gan grupu ietvaros ir atrodamas gēnā, kas kodē G proteīnu, tādēl tā nepilna sekvenēšana bieži tiek izmantota molekulāri epidemioloǵiskos pētījumos. Pilna genoma analīze ir apstiprinājusi, ka mainība G gēnā atspoguḷo vispārējo vīrusa variabilitāti [Rebuffo-Scheer et al., 2011; Tan et al., 2012].

G ir virsmas glikoproteīns, kura struktūrā ietilpst divi mucīnam līdzīgi hipervariabli reǵioni (HVR1 un 2) [Johnson et al., 1987]. Sekvenču dažādība HVR segmentos ir viena no lielākajām, kāda novērota starp cilvēka vīrusiem. Šì variabilitāte atspoguḷo gan saimnieka organisma imūnās sistēmas radītu selekciju, gan proteīna strukturālo plasticitāti [Collins and Melero, 2011]. Mucīnam līdzīgie reǵioni ir izteikti glikozilēti ar O- un N-saites veidojošu ogḷhidrātu ķēēēm, kuru pozīciju skaits un vieta nav konservatīvi starp dažādiem celmiem, tādējādi pastiprinot HRSV antigēnās atšķirības [Johnson et al., 1987; Martinez et al., 1997; Palomo et al., 1991].

Reǵionālai HRSV molekulārajai uzraudzībai ir būtiska nozīme HRSV virusoloǵisko īpašību izpētē, jaunu virulences faktoru prognozēšanā, diagnostisko testu izstrādē un populācijai piemērotu vakcīnu celmu selekcijā. Apkopojot vietējos un globālos datus, ir iespējams rekonstruēt vīrusa populācijas izmēra pārmaiņas un ǵeogrāfisko izplatību, kas l̦auj identificēt epidēmijas izplatīšanās cel̦us un veicināt sabiedrības veselības stratēǵiju izstrādāšanu. Latvijā cirkulējošo HRSV celmu molekulārā struktūra iepriekš nav pētīta. 


\subsection{Darba mērḳis}

Raksturot HRSV izraisīto dziḷāko elpceḷu infekciju klīniskās īpatnības un Latvijas terciārā līmeņa bērnu slimnīcā cirkulējošo celmu molekulāro epidemiolog̣iju trīs secīgu respiratoro vīrusu sezonu laikā.

\subsection{Darba uzdevumi}

1. Izstrādāt polimerāzes ķēdes reakcijas (PCR) testu HRSV diagnostikai un genētisko grupu diferencēšanai;

2. noteikt HRSV izplatību stacionētiem agrīna vecuma bērniem ar dziḷāko elpcel̦u infekciju;

3. izpētīt HRSV sezonalitāti trīs gadu laikā;

4. noteikt HRSV grupu un genotipu iespējamo saistību ar to izraisītās infekcijas smagumu;

5. analizēt HRSV celmu filoǵenēzi un mainību;

6. izmantojot G gēna genealog̣iju, rekonstruēt HRSV demogrāfiskās un g̊eogrāfiskās izkliedes parametrus.

\subsection{Darba hipotēzes}

1. HRSV molekulārā epidemiolog̣ija Latvijā būtiski neatšḳiras no citām valstīm, tomēr pastāv lokālo celmu iespējamība;

2. pastāv korelācija starp HRSV molekulāro raksturojumu un slimības norises smagumu; 
3. pielietojot molekulārā pulksteņa principu ar izolēšanas laiku un vietu iezīmētām HRSV genoma sekvencēm, iespējams rekonstruēt tā globālo izplatīibu.

\subsection{Zinātniskā novitāte}

Šis ir pirmais HRSV molekulārās epidemiologijas pētījums Latvijā un tam ir gan lokāla, gan globāla zinātniskā novitāte. Tas aktualizē precīzu HRSV sezonalitātes datu nepieciešamību Latvijā. Tika atklāti vairāki jauni HRSV celmi, kuru sekvences ir deponētas GenBank datu bāzē. Šis pētījums ir pirmais, kas izvirza genotipa ON1 migrēšanas hipotēzi un populācijas dinamikas aplēses. Iegūtie dati var tikt izmantoti optimālākai imūnprofilakses pielietošanai riska grupas zīdaiņiem Latvijā un globālo sabiedrības veselības stratēgiju plānošanā.

Šajā darbā visi publicētie rezultāti ir autora paša veikums darba zinātnisko vadītāju uzraudzībā. Promocijas darba "Cilvēka respiratorā sincitiālā vīrusa izraisīto dzil̄āko elpceļu infekciju klīniskais un molekulārais raksturojums hospitalizētiem bērniem Latvijā̄" aprobācija notika Rīgas Stradiņa universitātes Pediatrijas katedras paplašinātajā sēdē 2013. gada 2. septembrī. 


\section{METODES}

\subsection{Pētījuma populācija}

Šis prospektīvais kohortas pētījums tika veikts Valsts sabiedrībā ar ierobežotu atbildību „Bērnu klīniskā universitātes slimnīca” Torņakalna novietnē (BKUS) laika posmā no 2009. gada 1. jūlija līdz 2012. gada 30.

jūnijam. Pētījums saņēma RSU Ētikas komitejas aţ̦auju, un informētu piekrišanu dalībai tajā parakstīja visu iekḷauto pacientu vecāki. Par iekḷaušanas kritērijiem kalpoja: (1) bērna vecums, 2-24 mēneši, un (2) atbilstîba PVO dzil̄āko elpcel̦u infekcijas gadījuma definīcijai [Wright and Cutts, 2000]. Par izslēgšanas kritērijiem tika noteikti: (1) hroniskas pavadošas centrālās nervu sistēmas un kardiopulmonālas slimības un (2) pacienti, kuru simptomi bija ilgāki par 10 dienām.

Pacientu klīniskie dati tika objektivizēti, izmantojot punktu skalas: respiratorā distresa novērtēšanas instruments (RDNI; elpošanas mazspēja no 017) [Lowell et al., 1987] un Klīniskā smaguma skala (KSS; slimības smagums 0-6) [Martinello et al., 2002], kā arī izmantojot sistēmiskā iekaisuma atbildes sindroma (SIRS) kritērijus [Goldstein et al., 2005].

\subsection{Klīniskie paraugi}

No katra pētījumā iekḷautā pacienta tika iegūts nazofaringeālais aspirāts (NFA). NFA paraugi tika nekavējoties iesaldēti un uzglabāti pie $-70^{\circ} \mathrm{C}$ līdz turpmākai analīzei. Kopējā ribonukleīnskābe (RNS) tika izolēta no $140 \mu 1$ NFA parauga, izmantojot komerciālu RNS izolēšanas kitu (QIAamp Viral RNA, 
QIAGEN) saskaņā ar ražotāja rekomendācijām. Izdalītā RNS kalpoja par matricu HRSV molekulārās diagnostikas testu izstrādei.

\subsection{HRSV diagnostika, grupu diferencēšana, sekvenēšana}

HRSV specifiskā komplementārā dezoksiribonukleīnskābe (cDNS) tika sintezēta ar apgrieztās transkripcijas polimerāzes ķēdes reakciju (RT-PCR), izmantojot RevertAid ${ }^{\mathrm{TM}}$ Premium apgriezto transkriptāzi (Fermentas) ar 12,5 $\mu \mathrm{l}$ izdalītās RNS un 20 pmol praimeri F164_Rv (3.1. attēls) [Sellender et al., 1993], saskaņā ar ražotāja rekomendācijām.

Pirmkārt, HRSV specifiskās RNS klātbūtne tika detektēta ar PCR, amplificējot genētiski konservatīvu genoma rajonu starp P un M gēniem, neatkarīgi no vīrusa antigēnās grupas (3.1. attēls). Otrkārt, pozitīvajiem paraugiem tika noteikta piederība galvenajām grupām, HRSV-A un B, veicot grupu specifisku PCR G gēna HVR2 segmentam. Šajā reakcijā apgrieztais praimeris F_Rv bija kop̄̄gs abām grupām, bet tiešie praimeri bija grupu specifiski: Ga_Fw A grupai un Gb_Fw B grupai (3.1. attēls). Amplificētie fragmenti tika analizēti elektroforētiski ar etīdija bromīdu krāsotā 1\% agarozes gēlā.

Grupu diferencēšanas PCR produkti tika izdalīti no agarozes gēla un sekvenēti, izmantojot apgriezto praimeri $\mathrm{F}$ _Rv un tiešos praimerus Ga_Fw (HRSV-A) un Gb_Fw (HRSV-B). Šādā veidā pēc datu apstrādes tika iegūtas 336 nukleotīdu (nt) garas HRSV-A (kodonu pozīcijas 187-299 atbilstoši references celma A2 sekvencei) un 516 nt garas HRSV-B (kodonu pozīcijas 140-293 atbilstoši references celma B1 sekvencei) sekvences. Unikālās sekvences tika reǵistrētas GenBank datu bāze ar pieejas kodiem JF979145-47 un KF030137-85. 


\subsection{Filoğenēzes un adaptīvās evolūcijas analīze}

Pētījumā iegūtās HRSV nt un deducēto aminoskābju (aa) sekvences (lietojot universālo ǵenētisko kodu) tika izkārtotas kopā ar iepriekš publicētām sekvencēm, izmantojot ClustalW2 algoritmu [Larkin et al., 2007]. Filoǵenētiskie koki tika konstruēti ar neighbor-joining (NJ) ātrās klasterizācijas algoritmu [Saitou and Nei, 1987] un genēetiskās distances (vidējais nt un aa substitūciju skaits katrā novietojumā starp visiem sekvenču pāriem) tika aprēķinātas, izmantojot datorprogrammu MEGA v5.1 [Tamura et al., 2001]. Aprēķinu statistiskā nozīmība tika pārbaudīta ar sākumpalaišanas protokolu², izmantojot 1000 kopijas. O-glikozilācijas pozīcijas tika noteiktas, izmantojot $\begin{array}{llll}\text { NetOGlyc } & 3.1 & \text { servera neirālā tīkla prognozes }\end{array}$ (http://www.cbs.dtu.dk/services/NetOGlyc/) [Julenius et al., 2005], bet $\mathrm{N}$ glikozilācija tika prognozēta, izmantojot NetNGlyc 1.0 serveri (http://www.cbs.dtu.dk/services/NetNGlyc/) [Gupta et al., 2004].

Kodoni, kuri atrodas zem pozitīvās selekcijas spiediena, tika noteikti ar katrai pozīcijai specifisku ne-sinonīmo $(d N)$ / sinonīmo $(d S)$ mutāciju attiecību (dN/dS), izmantojot piecus dažādus algoritmus, kas pieejami Datamonkey serverī (http://www.datamonkey.org/) [Delport et al., 2010]: SLAC, FEL, REL, IFEL un MEME. Tika pieņemts, ka kodons atrodas zem pozitīvas selekcijas selekcijas spiediena, kad divas vai vairāk metodes tā pozīcijā aprēķināja $d N / d S$ $>1$ ar statistisku nozīmību ( $<<0,1$ vai Baijesa faktors $>20$ ) kā to rekomendē [Kosakovsky Pond et al., 2005]. Vidējā $d N / d S$ attiecība tika noteikta, izmantojot SLAC algoritmu.

\footnotetext{
${ }^{2}$ Bootstrap
}

14 


\subsection{Evolūcijas ātrums, populācijas dinamika un filoğeogrāfiskāā analīze}

Nukleotīdu substitūciju ātrums pozīcijā, kopīgā ciltstēva laiks (tMRCA $)^{3}$, vīrusa populācijas apjoma izmaiņas un diskrētā filoǵeogrāfiskāa analīze tikai aprēķināti, ar laiku un lokalizāciju iezīmētām sekvencēm pielietojot Baijesa Markova ķēes Montekarlo (MCMC) ${ }^{4}$ metodi datorprogrammā BEAST v2.0.2 [Drummond et al., 2012]. MCMC analīzes rezultāti tika izvērtēti, izmantojot datorprogrammu Tracer v1.5, un maksimālās radniecības ticamības $(\mathrm{MCC})^{5}$ filoǵenētiskais koks tika konstruēts, izmantojot datorprogrammu TreeAnnotator v2.0.2. MCC koks tika vizualizēts, izmantojot datorprogrammu FigTree v1.4.0. Datu nenoteiktība tika izteikta kā 95\% augstākās varbūtības blīvums, HPD $^{6}$.

\subsection{Datu statistiskā apstrāde}

Klīnisko datu statistiskai apstrādei tika izmantota datorprogrammas SPSS 17.0 un Microsoft Excel 2010. Intervālu un rangu skalas dati tika salīdzināti, izmantojot Manna-Vitnija testu, bet nominālie dati tika salīdzināti, izmantojot Pīrsona $\chi^{2}$ vai Fišera testu. Atšķirības tika uzskatîtas par statistiski nozīmīgām, ja p <0,05.

\footnotetext{
${ }^{3}$ Time of most recent common ancestor.

${ }^{4}$ Markov chain Monte Carlo.

${ }^{5}$ Maximum Clade Credibility.

${ }^{6}$ Highest probability density.
} 


\section{REZULTĀTI}

\subsection{Pētījuma pamatgrupa}

Kopumā pētījumā tika iekḷauti 207 pacienti (67-71 pacienti sezonā). Pacientu vecuma mediāna bija 8 (starpkvartīḷ izkliede 4-14) mēneši, no tiem 36\% bija vecumā līdz 6 mēnešiem un kopā 68\% vecumā līdz 12 mēnešiem. Katra pacienta paraugam tika piešķirts kods pēc sekojošas shēmas: LV (Latvija)/parauga numurs pēc kārtas attiecīgajā gadā/parauga ņemšanas gads.

\subsection{HRSV diagnostika un grupu diferencēšana}

Veicot primāro skrīningu, 509 bp PCR fragments bija viegli detektējams agarozes gēlā (3.1. attēls). Šādā veidā HRSV specifiskas RNS klātbūtne tika noteikta 88 (42,5\%) no 207 pārbaudītajiem paraugiem. Veicot HRSV grupu diferencēšanu, praimeri tika konstruēti tā, lai HRSV-A un B varētu viegli izšķirt pēc amplificētā fragmenta garuma (3.1. attēls). Šādi tika pārbaudīti visi 88 HRSV-pozitīvie paraugi; 53 (60,2\%) uzrādīja A grupai un 35 $(39,8 \%)$ B grupai atbilstošu fragmenta garumu. Nevienā gadījumā netika konstatēta abu grupu ko-infekcija. 


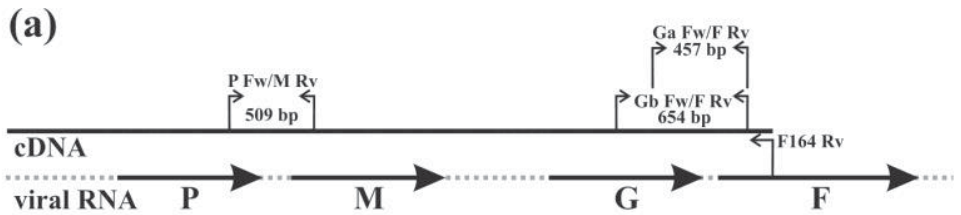

(b)

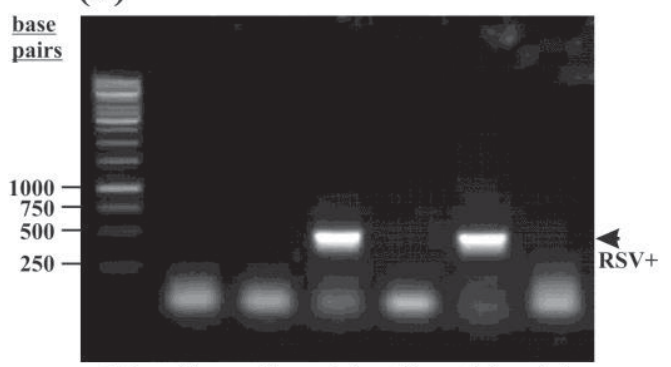

$\begin{array}{lllllll}M & (-) & (-) & (+) & (-) & (+) & (-)\end{array}$ (c)

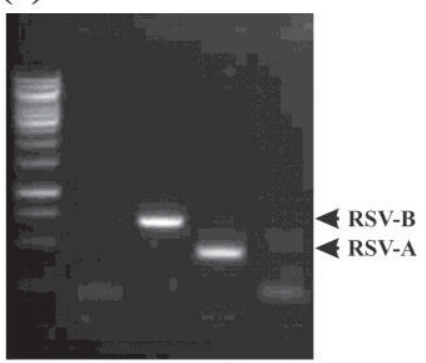

$\mathbf{M} \quad \mathbf{A}(-) \mathbf{B}(+) \mathbf{A}(+) \mathbf{B}(-)$

3.1. att. HRSV molekulārās diagnostikas stratēǵija

A, shematiski attēlota dal̦a no HRSV genoma un PCR diagnostikas stratēgija; B un C, agarozes gēla elektroforēze, kas ilustrē primāro HRSV skrīningu ar praimeriem P_Fw/M_Rv (B) un HRSV pozitīvo paraugu grupu diferencēšanu (C). M, DNS molekulārās masas marķiēris (Fermentas); (+) pozitīva reakcija; (-) negatīva reakcija.

Paralēli PCR analīzei, 110 pacientiem tika ņemtas arī deguna iztriepes virusoloǵiskajai diagnostikai ar tiešo imūnfluorescences testu (IFA). Šis izmeklējums neietilpa pētījuma programmā un tika veikts pēc ārstējošā ārsta ieskatiem. Salīdzinot RT-PCR ar IFA kā "zelta standartu”, tika iegūta jutība 95,2\%, specifiskums - 91,2\%, pozitīvā paredzamā vērtība - 87\% un negatīvā paredzamā vērtība $-97 \%$.

\subsection{HRSV sezonalitāte}

Kopējā HRSV-pozitīvo paraugu proporcija atkarībā no sezonas bija 33,3\% līdz 56,7\%, bet sezonu augstākās aktivitātes periodā varēja sasniegt pat $90 \%$ (3.2. attēls). 


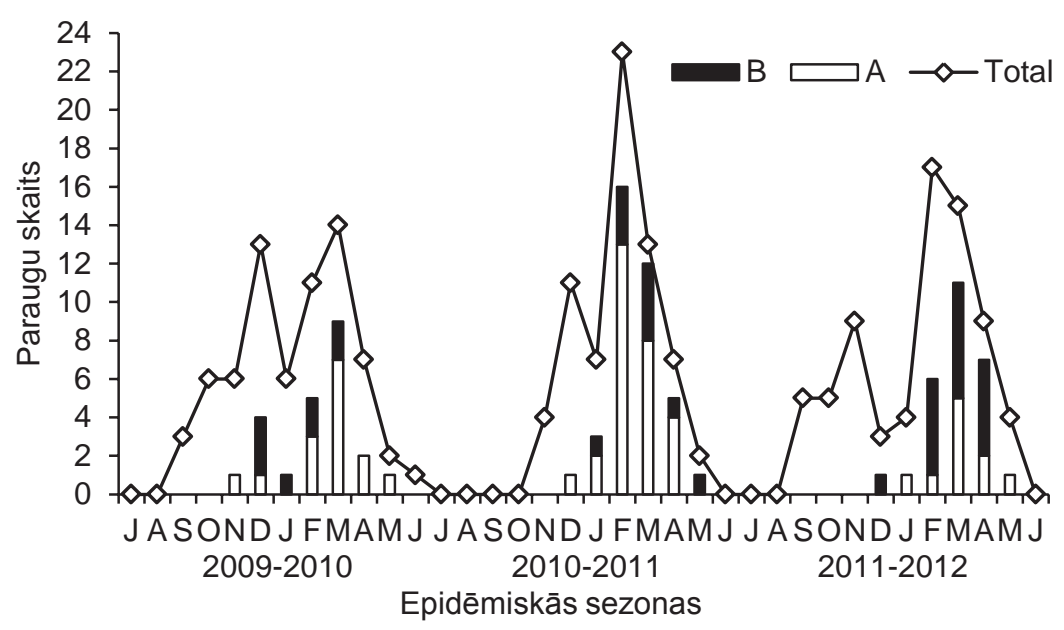

\section{2. att. HRSV pozitīvo paraugu sadalījums pa pētījuma mēnešiem}

Kopējais pārbaudīto paraugu skaits (līkne) un HRSV-A (baltie stabinini) un B (melnie stabiṇi) pozitīvo paraugu skaits katrā mēnesī. Mēneši norādīiti ar tā pirmo burtu, sākot no 2009. gada jūlija

HRSV epidemiologiiskās aktivitātes sākums tika noteikts kā pirmā no divām secīgām nedẹlām, kurās $\geq 10 \%$ testēto paraugu ir HRSV pozitīvi, savukārt beigas kā pēdējā no divām secīgām nedēlāam, kurās $\geq 10 \%$ testēto paraugu ir HRSV pozitīvi. Analizējot kopā trīs sezonu datus, HRSV epidemioloǵiskās aktivitātes periods tika noteikts no 51. līdz 19. gada nedēḷai. Šajā periodā HRSV izraisīja 57\% (86 no 151) dziḷāko elpecel̦u infekcijas, 92,9\% (26 no 28) bronhiolītu un 51,4\% (18 no 35) pneimoniju. Savukārt, ārpus šī perioda HRSV izrasīja tikai 3,6\% (2 no 56) dziḷāko elpceļu infekciju.

\subsection{Klīniskais salīdzinājums}

Veicot HRSV izraisītu dziḷāko elpceḷu infekciju klīnisko salīdzinājumu ar citu etioloǵijas grupu (respektīvi, "ne-HRSV" grupa), tika konstatēta virkne atšķirību (3.1. tabula): (i) ar HRSV inficētie pacienti bija statistiski ticami 
jaunāki, (ii) viniiem biežāk ğimenes anamnēzē bija atopiskas saslimšanas, bet (iii) retāk tika noteikts SIRS. Atšḳīrās arī noteiktās diagnozes - HRSV biežāk izraisīja bronhiolītu, bet netika diagnosticēts nevienam no pacientiem ar obstruktīvu laringotraheītu (krupu). Savukārt, neatšķīrās neviens no lietotajiem slimības smaguma rādītājiem - prasība pēc skābekḷa inhalācijas, RDNI, KSS, un hospitalizācijas ilguma. Pētījuma laikā nomira viens $(0,5 \%)$ pacients ar dziḷāko elpcel̦u infekciju, kas bija HRSV negatīvs.

3.1. tabula

HRSV izraisītu un citas etioloğijas dziḷāko elpceḷu infekciju klīniskais salīdzinājums

\begin{tabular}{|c|c|c|c|}
\hline Pazīme & HRSV & Ne-HRSV & $\begin{array}{c}\mathrm{P} \\
\text { vērtība }\end{array}$ \\
\hline Pacientu skaits & 88 & 119 & \\
\hline Meitenes, sk. (\%) & $38(43,2)$ & $42(35,3)$ & 0,249 \\
\hline $\begin{array}{l}\text { Vecums mēnešos, mediāna (starpkvartịḷu } \\
\text { izkliede) }\end{array}$ & $6(3-9,25)$ & $10(6-16,5)$ & $<\mathbf{0 , 0 0 1}$ \\
\hline $\begin{array}{l}\text { Svars atbilstoši vecumam, z-vērtības mediāna } \\
\text { (starpkvartīl lu izkliede) }\end{array}$ & $\begin{array}{c}0,69(-0,17- \\
1,24)\end{array}$ & $\begin{array}{c}0,84(0,04- \\
1,36)\end{array}$ & 0,252 \\
\hline Pasīvā smēķēšana, sk. (\%) & $59(67)$ & $68(57,1)$ & 0,148 \\
\hline $\begin{array}{l}\text { Apdzīvotības indekss, mediāna }{ }^{a} \text { (starpkvartīlu } \\
\text { izkliede) }\end{array}$ & $1,7(1,3-2)$ & $1,7(1,3-2)$ & 0,424 \\
\hline Atopiskas slimības ǵimenē, sk. (\%) & $50(56,8)$ & $51(42,9)$ & 0,047 \\
\hline $\begin{array}{l}\text { Sistēmiskā iekaisuma atbildes sindroms } \\
\text { (SIRS), sk. (\%) }\end{array}$ & $17(19,3)$ & $79(66,4)$ & 0,023 \\
\hline Prasība pēc skābekla, sk. (\%) & $27(30,7)$ & $46(38,7)$ & 0,235 \\
\hline $\begin{array}{l}\text { Respiratorā distresa novērtēšanas instruments, } \\
\text { mediāna (starpkvartīḷ izkliede) }\end{array}$ & $6(5-8)$ & $6(4-8)$ & 0,839 \\
\hline Klīniskā smaguma skala, moda (izkliede) & $1(1-6)$ & $1(0-5)$ & 0,21 \\
\hline Antibakteriāla terapija, sk. (\%) & $31(35,2)$ & $45(37,8)$ & 0,703 \\
\hline $\begin{array}{l}\text { Stacionēšanas ilgums, mediāna (starpkvartịlu } \\
\text { izkliede) }\end{array}$ & $4(3-6)$ & $4(2-6)$ & 0,651 \\
\hline Diagnoze & & & $<0,001$ \\
\hline Bronhīts & $40(45,5)$ & $55(46,2)$ & 0,913 \\
\hline Bronhiolīts & $27(30,7)$ & $13(10,9)$ & 0,001 \\
\hline Pneimonija & $19(21,6)$ & $33(27,7)$ & 0,398 \\
\hline Astma & $2(2,3)$ & $7(5,9)$ & 0,306 \\
\hline Krups & 0 & $11(9,2)$ & 0,002 \\
\hline
\end{tabular}

\footnotetext{
${ }^{a}$ aprēḳināts dalot cilvēku skaitu ǵimenē ar istabu skaitu. $\mathrm{P}$ vērtības $<0,05$ norādītas trekninājumā.
} 
58\% (n=51) bērnu ar HRSV infekciju bija vecumā līdz sešiem mēnešiem, salīdzinot ar 29,4\% $(n=35)$ citas etiologijas grupā $(p<0,001)$, bet 79,5\% (n=80) vecumā līdz gada vecumam, salīdzinot ar 64,7\% (n=64) citas etioloǵijas grupā $(\mathrm{p}=0,03)$.

Salīdzinot HRSV-A un B klīniskās pazīmes un pacientu demogrāfiskos datus, statistiski ticamas atšķirības netika konstatētas nevienā no salīdzinātajiem parametriem (3.2. tabula).

3.2. tabula

HRSV grupu A un B klīniskais salīdzinājums

\begin{tabular}{|c|c|c|c|}
\hline Pazīme & HRSV-A & HRSV-B & $\begin{array}{c}\mathrm{P} \\
\text { vērtība }\end{array}$ \\
\hline Pacientu skaits & 53 & 35 & \\
\hline Meitenes, sk. (\%) & $19(35,8)$ & $19(54,3)$ & 0,087 \\
\hline $\begin{array}{l}\text { Vecums mēnešos, mediāna (starpkvartịlu } \\
\text { izkliede) }\end{array}$ & $6(3-9)$ & $6(3,75-12)$ & 0,518 \\
\hline $\begin{array}{l}\text { Svars atbilstoši vecumam, z-vērtības mediāna } \\
\text { (starpkvartīḷ izkliede) }\end{array}$ & $\begin{array}{c}0,53(-0,2- \\
1,1)\end{array}$ & $\begin{array}{l}0,91(-0,01- \\
1,29)\end{array}$ & 0,279 \\
\hline Pasīvā smēķēšana, sk. (\%) & $37(69,8)$ & $22(62,9)$ & 0,497 \\
\hline $\begin{array}{l}\text { Apdzīvotības indekss, mediāna (starpkvartīḷu } \\
\text { izkliede) }\end{array}$ & $\begin{array}{c}1,7(1,3- \\
2,5)\end{array}$ & $1,6(1,4-2)$ & 0,552 \\
\hline Atopiskas slimības gimenē, sk. (\%) & $23(43,4)$ & $13(37,1)$ & 0,633 \\
\hline $\begin{array}{l}\text { Sistēmiskā iekaisuma atbildes sindroms } \\
\text { (SIRS), sk. (\%) }\end{array}$ & $12(22,6)$ & $5(14,3)$ & 0,331 \\
\hline Prasība pēc skābekḷa, sk. (\%) & $17(32,1)$ & $10(28,6)$ & 0,727 \\
\hline $\begin{array}{l}\text { Respiratorā distresa novērtēšanas instruments, } \\
\text { mediāna (starpkvartīḷu izkliede) }\end{array}$ & $6(4-8)$ & $7(5,5-8)$ & 0,928 \\
\hline Klīniskā smaguma skala, moda (izkliede) & $1(1-5)$ & $1(1-6)$ & 0,303 \\
\hline Antibakteriāla terapija, sk. (\%) & $20(37,7)$ & $11(31,4)$ & 0,544 \\
\hline $\begin{array}{l}\text { Stacionēšanas ilgums, mediāna (starpkvartīlu } \\
\text { izkliede) }\end{array}$ & $4(3-6)$ & $3(2-4,75)$ & 0,163 \\
\hline Diagnoze & & & 0,316 \\
\hline Bronhīts & $26(49,1)$ & $14(40)$ & 0,538 \\
\hline Bronhiolìts & $18(34)$ & $9(25,7)$ & 0,559 \\
\hline Pneimonija & $8(15,1)$ & $11(31,4)$ & 0,119 \\
\hline Astma & $1(1,9)$ & $1(2.9)$ & 1 \\
\hline
\end{tabular}




\subsection{Filog̀enētiskā analīze}

Salīdzinot nt sekvences, 53 HRSV-A un 35 HRSV-B izolāti tika sagrupēti attiecīgi 29 un 23 dažādos celmos. Šo celmu sekvences tika izkārtotas kopā ar GenBank pieejamajām celmu sekvencēm ar iepriekš noteiktiem genotipiem. Kopumā analīzē tika iekḷauti 11 HRSV-A genotipi (GA1-7 [Peret et al., 2000], SAA1 [Venter et al., 2001], NA1 un 2 [Shobugawa et al., 2009], ON1 [Eshaghi et al., 2012]) un 13 HRSV-B genotipi (GB1 - 4 [Peret et al., 2000], SAB1-3 [Venter et al., 2001], BA-I-IV [Trento et al., 2006]).

Latvijas HRSV-A izolāti piederēja diviem dažādiem genotipiem. 28 celmi (51 izolāts) piederēja genotipam NA1 (3.3. attēls). Viens celms, kurā ietilpa divas identiskas sekvences, kas tika izolētas 2012. gada martā, piederēja nesen aprakstītajam genotipam ON1 (3.3. attēls). Visiem HRSV-B izolātiem tika konstatēta 60 nt duplikācija G gēnā, kas raksturīga BA genotipiem, un tie visi piederēja BA-IV genotipam (3.4. attēls). 


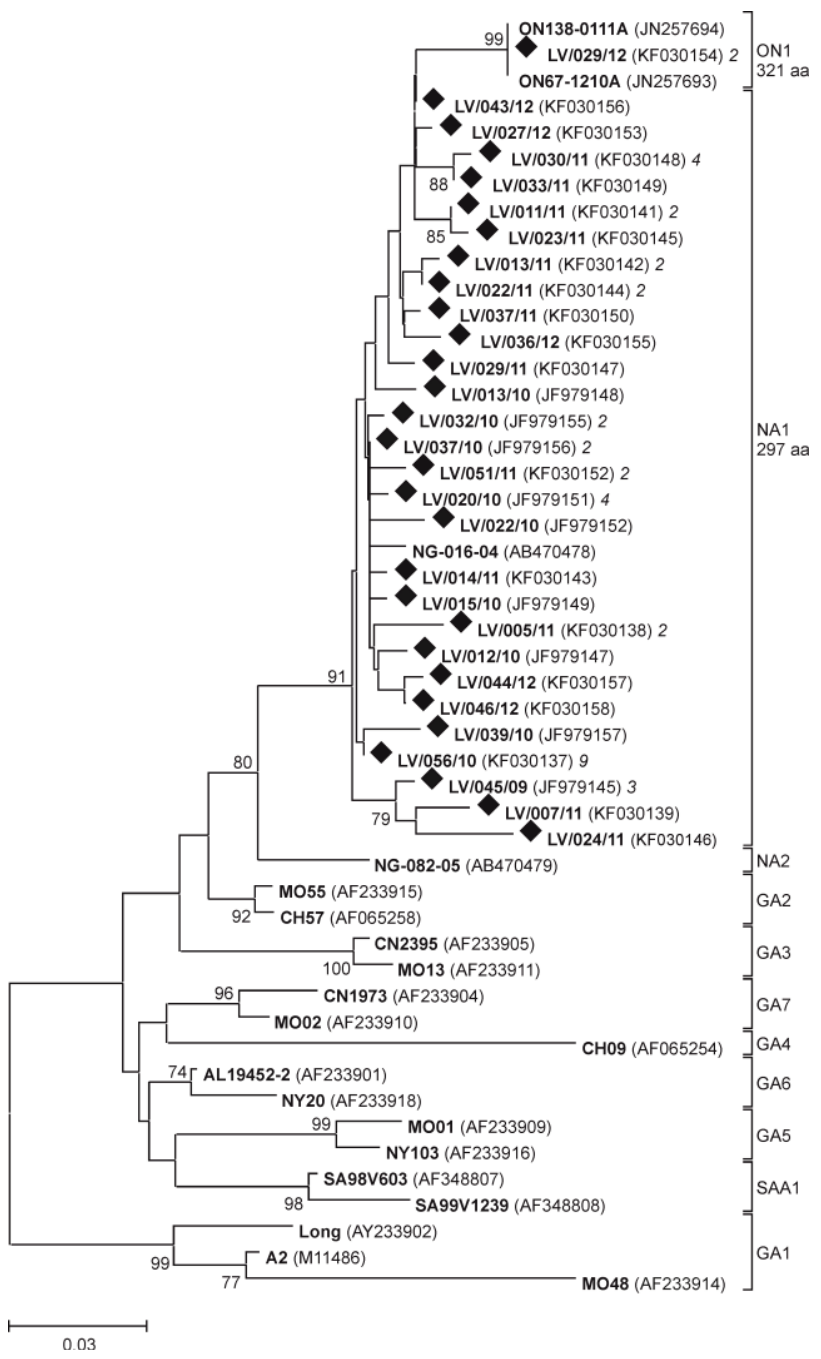

\section{3. att. HRSV A grupas filoǵenētiskais koks}

Latvijas celmi ir apzīmēti ar $(\diamond)$. Taksonu apzīmējumi ietver: celma nosaukumu (trekninājumā), iekavās norādītu GenBank pieejas kodu un kursīvā norādītu identisko izolātu skaitu.

Sākumpalaišanas vērības, kas $\geq 70$, norādītas mezglos. Skala norāda nukleotīdu substitūciju skaitu pozīcijā. 


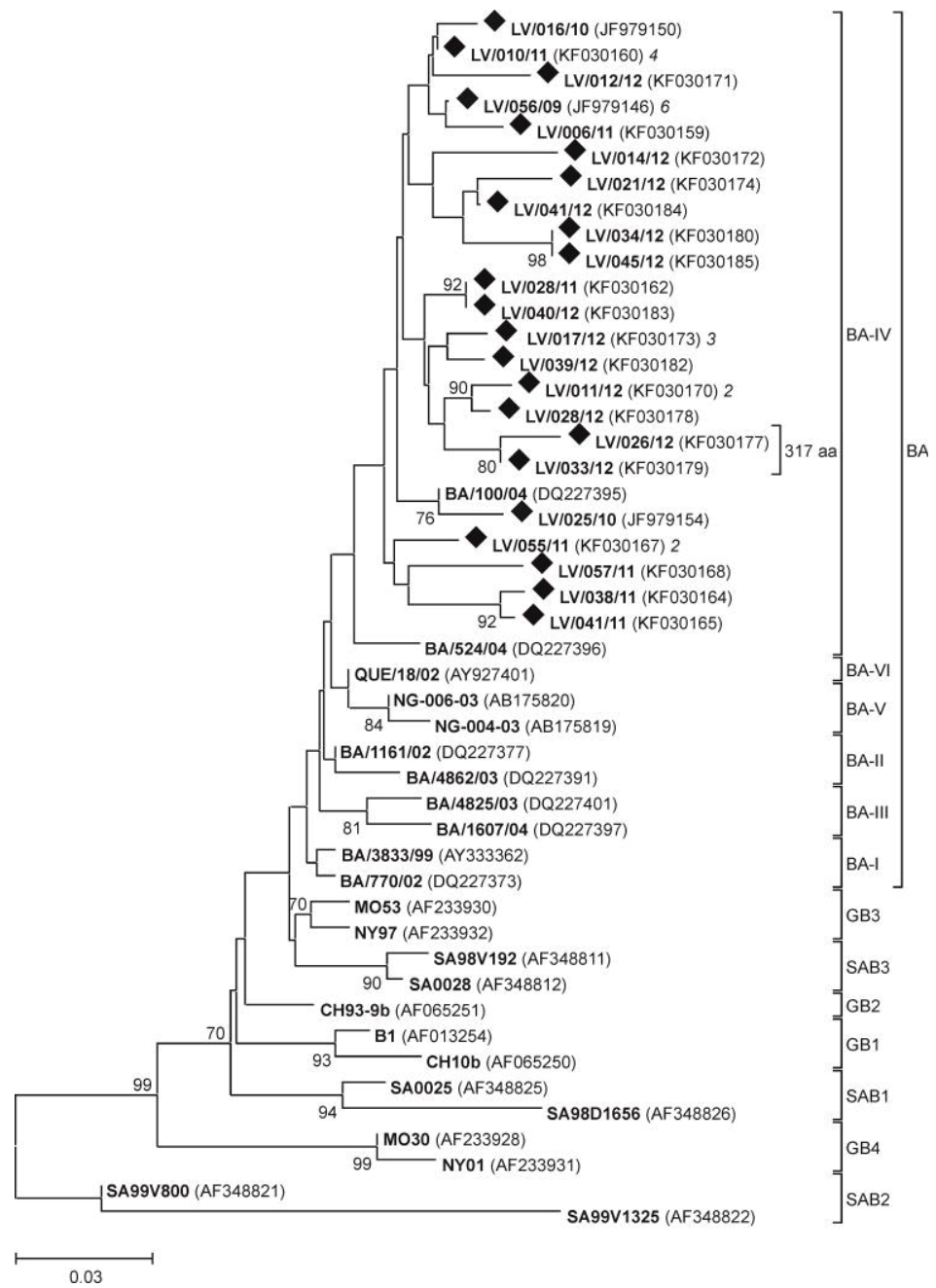

\section{4. att. HRSV B grupas filoǵenētiskais koks}

Apzīmējumi lietoti kā 3.3. attēla aprakstā. Celmi ar 317 aminoskābju garu G proteīnu ir norādīti atsevišķi, pārējiem celmiem bija 310 aminoskābju garš $\mathrm{G}$ proteīns. 


\subsection{Genotipa NA1 molekulārais raksturojums}

Genotipa NA1 Latvijas celmu HVR2 sekvences bija savstarpēji cieši saistītas, un genētiskie attālumi bija 2,1\% $( \pm 0,4)$ un 4,1\% $( \pm 0,9)$ attiecīgi nt un aa līmenī. Visiem HRSV-A celmiem bija priekšlaicīgs terminācijas kodons (TGA) 298. pozīcijā un saglabāts oriǵinālais (celma A2) terminācijas kodons 299. pozīcijā (3.5. attēls). Visiem NA1 celmiem tika atklātas arī sekojošas mutācijas: $P 226 \rightarrow L, E 233 \rightarrow K, L 258 \rightarrow H / Y, M 262 \rightarrow E / R, F 265 \rightarrow L, S 269 \rightarrow T$, $S 280 \rightarrow Y, P 289 \rightarrow S, S 290 \rightarrow P / L, P 292 \rightarrow S, P 293 \rightarrow S, P 296 \rightarrow T$ un $R 297 \rightarrow K$. Citas biežas $(>50 \%$ celmu) mutācijas bija: L208 $\rightarrow I, \quad S 222 \rightarrow P, \quad N 237 \rightarrow D$, $I 244 \rightarrow R, N 273 \rightarrow Y / K, P 274 \rightarrow L$ un $P 286 \rightarrow L$.

Izmantojot NetOGlyc 3.1 serveri, potenciāla $O$-glikozilācija tika prognozēta 40 serīna un treonīna atlikumiem (starp individuāliem celmiem no 36 līdz 43). Analogā celma A2 sekvencē tika prognozētas 39 O-glikozilācijas vietas, no kurām 36 bija kopīgas ar Latvijas konsensa sekvenci. Celma A2 HVR2 segmentā ir divi potenciāli $N$-glikozilācijas motīvi - N237 un N251. Starp Latvijas celmiem bija sastopami vēl divi motīvi - N273 un N294. NetNGlyc 1.0 serveris prognozēja tikai N251 un N294 N-glikozilāciju Latvijas konsensa sekvencē. Starp individuāliem celmiem prognozētās $N$-glikozilācijas pozīcijas variēja no 0 līdz 3 . Neviens no $N$-glikozilācijas motīviem nebija kopīgs visiem izolātiem.

Kopumā 28 pozīcijās bija paaugstināta ne-sinonīmo nomaiņu $(d N)$ proporcija un vidējā ne-sinonīmo/sinonīmo nomaiņu $(d N / d S)$ attiecība bija 1,12, kas liecina par selekcijas spiediena klātbūtni. Neskatoties uz to, tikai divas pozīcijas, M262 un N273, tika noteiktas balstoties uz divu vai vairāk metožu konsensu. 
HRSV-A

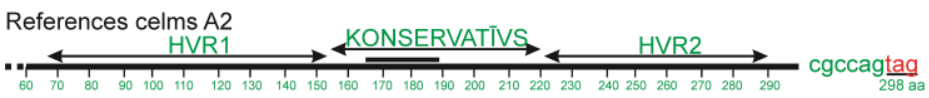

(I)

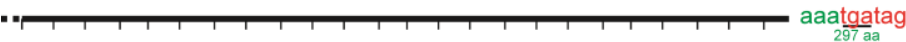

(II)

QEETLHSTTSEGYLSPSQVYTTS (G)QEETLHSTTSEGYLSPSQVYTTS

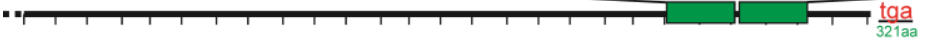

HRSV-B

References celms B1

caaaatacccaatcacatgcttag

(III) PK TERDTSTSQSTVLDTTTSKH TERDTSTSQSIVLDTTTSKH

(IV)

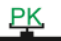

caaaatacccaatcacatgcttag

\section{5. att. Latvijas izolātu $G$ proteīna ektodomēna variabilitāte}

Lineārais attēlojums ir balstīts uz prototipu celmu A2 un B1 sekvencēm. I, priekšlaicīgs terminācijas kodons (pasvītrotie nukleotīdi), kas terminē 297 aminoskābju garu proteīnu, ir raksturīgs visiem Latvijas HRSV-A izolātiem. II, diviem HRSV-A izolātiem tika konstatēta 72 nukleotīdu duplikācija (zalš taisnstūris) otrajā hipervariablajā rajonā. III, sešu nukleotīdu delēcija (•), 60 nukleotīdu duplikācija un priekšlaicīgs terminācijas kodons, veidojot 310 aminoskābju garu proteīnu, ir raksturīgi lielākajai daļai Latvijas HRSV-B izolātu. IV, diviem HRSV-B izolātiem bija saglabāts oriǵinālais celma B1 terminācijas kodons, šie proteīni bija 317 aminoskābju gari.

Diagrammu atainojums un izmantotie simboli lietoti kā [Zlateva et al., 2005].

\subsection{Genotipa BA-IV molekulārais raksturojums}

Latvijas BA-IV genotipa celmi bija vairāk atšķirīgi ar aprēķinātajām genētiskajām distancēm 3,3\% $( \pm 0,4)$ un 4,2 \% $( \pm 0,7)$ attiecīgi nt un aa līmenī. Papildus raksturīgajai 20 aa „rāmja” duplikācijai HVR2 segmentā visiem Latvijas BA-IV celmiem tika konstatēta arī delēcija P159-K160 (3.5. attēls). Tika novērotas divas alternatīvas terminācijas kodonu lokalizācijas, tādējādi Latvijas HRSV-B vīrusi producēja 310 vai 317 aa garus G proteīnus (3.5. attēls). Visiem HRSV-B celmiem bija sekojošas mutācijas: $K 218 \rightarrow T, L 223 \rightarrow P$ 
un $S 247 \rightarrow P$. Papildus tām, biežas ( $>50 \%$ celmu) bija arī: $L 219 \rightarrow P, T 270 \rightarrow I / F$, $V 271 \rightarrow A, H 287 \rightarrow Y$ un $Q 313 \rightarrow$ Stop.

NetOGlyc 3.1 serveris prognozēja 44 serīna un treonīna atlikumu $O$ glikozilāciju Latvijas konsensa sekvencē (36-50 starp individuāliem celmiem) un 41 analogā references celma BA/3833/99 sekvencē (sākotnēji 1999. gadā izdalītais BA celms no Argentīnas). Tikai 16 no paredzētajām $O$-glikozilācijas pozīcijām sakrita ar HRSV-A konsensa sekvenci. Celma BA/3833/99 HVR2 segmentā ir divi potenciāli $N$-glikozilācijas motīvi - N296 un N310. N296 bija konservatīvs un tā glikozilācija tika prognozēta visiem Latvijas celmiem, bet N310 glikozilācija tika prognozēta tikai 317 aa garajās sekvencēs. Celmam LV/057/10 bija uzreiz trīs papildus motīvi (N212, N230 un N253), no kuriem diviem (N212 un N230) tika prognozēta $N$-glikozilācija.

Kopumā 32 pozīcijās bija paaugstināta ne-sinonīmo nomaiņu $(d N)$ proporcija, un vidējā ne-sinonīmo/sinonīmo nomaiņu (dN/dS) attiecība bija 0,45. Balstoties uz divu metožu sakritību, diviem kodoniem, L219 un T270, tika konstatēts pozitīiās selekcijas spiediens.

\subsection{Genotipa ON1 globālā filodinamika un filogeogrāfija}

Divi vienādi HRSV-A izolāti (LV/029/12) piederēja nesen aprakstītajam genotipam ON1, un to sekvences bija identiskas sākotnēji aprakstītā izolāta sekvencei no Kanādas. Genotipu ON1 raksturo 72 nt duplikācija HVR2 segmentā, kas izraisa indel mutāciju E284 $\rightarrow$ G un duplikāciju Q261-S283, pagarinot $G$ proteīnu par 24 aa ar rezultējošo garumu 321 aa (3.5. attēls) [Eshaghi et al., 2012]. Kopš atklāšanas Kanādā 2011. gadā, šis jaunais genotips ir izolēts vismaz deviṇās dažādās valstīs Ziemeḷamerikā, Eiropā, Āfrikā, Āzijā un Okeānijā. Kopumā līdz 2013. gada jūnijam GenBank bija pieejamas 42 
sekvences, 16 no tām bija identiskas celmam ON67-1210A [Cui et al., 2013; Eshaghi et al., 2012; Khor et al., 2013; Lee et al., 2012; Prifert et al., 2013; Valley-Omar et al., 2013].

No GenBank iegūtās un Latvijas ON1 sekvences tika izkārtotas un izmantotas, lai aprēķinātu maksimālās radniecības ticamības (MCC) filoǵenētisko koku (3.6. attēls). Veicot Baijesa MCMC analīzi, HVR2 segmenta evolūcijas ātrums tika aprēķināts $7,92 \times 10^{-3}$ nt substitūcijas/pozīcijā/gadā (95\% HPD: $2.97 \times 10^{-3}-1.28 \times 10^{-2}$ ), un kopīgā ciltstēva laiks (tMRCA) tika aprēķināts 2010. gada augusts (95\% HPD: 2009. gada septembris - 2011. gada janvāris).

Filoǵeogrāfiskā analīze ar labu statistisko atbalstu liecina, ka vīruss sākotnēji izplatīijies no Kanādas uz Itāliju un Vāciju un tālāk uz pārējo pasauli (aposteriorā varbūtība >0,7). Ticama ir arī vīrusa diseminācija no Vācijas uz Japānu un atgriešanās Vācijā no Dienvidkorejas un Japānas. Tomēr šī vīrusa migrāciju uz Latviju caur Malaiziju ir ar mazu statistisko atbalstu (aposteriorā varbūtība 0,03; 3.6. attēls). Baijesa apvāršņa grafiks demonstrē, ka ON1 efektīvās populācijas izmērs lēni pieauga, sasniedza plato 2012. gada sākumā un nedaudz samazinājās pirms 2012./2013. sezonas (3.6. attēls). 


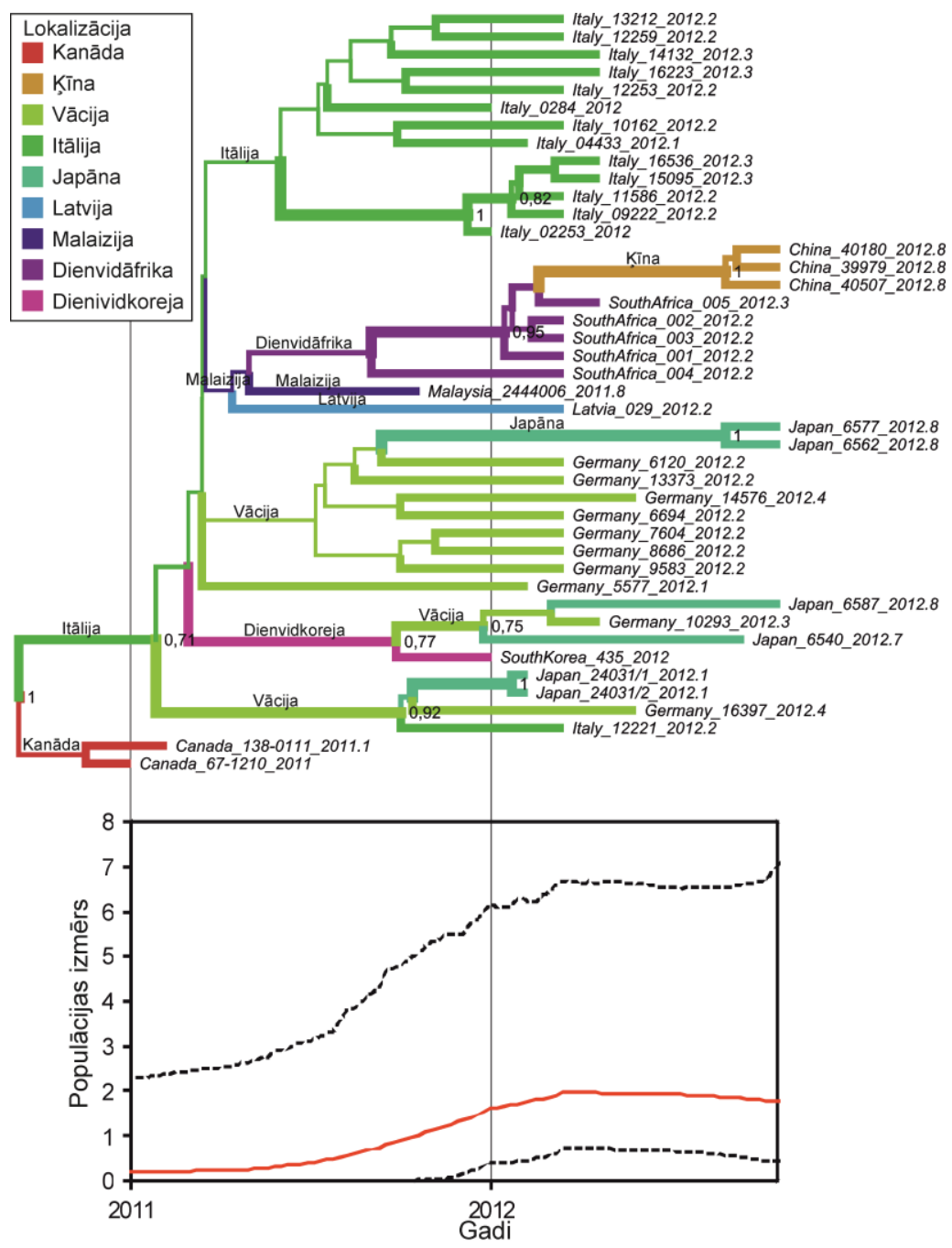

3.6. att. Genotipa ON1 diskrētā filog̣eogrāfiskā analīze un demogrāfiskā vēsture

Maksimālās radniecības ticamības (MCC) filoğenētiskais koks (augšējais panelis) un Baijesa apvāršña grafiks (BSP; apakšējais panelis). Zaru krāsa norāda uz lokalizāciju (skat. leǵendu), un platums korelē ar aposterioro varbūtību (vērtības $>0.7$ ir norādītas mezglos). BSP $y$ ass norāda uz populācijas izmēru, kas izteikts efektīvās populācijas (Ne) reizinājumā ar paaudzes ilgumu gados $(\tau)$, iegūtā vērtība ir proporcionāla incidencei [Frost and Volc, 2010]. Sarkanā nepārtrauktā līnija atbilst mediānai, un laukums starp punktētajām līnijām atbilst 95\% HPD robežām. Abi grafiki ir atainoti vienā laika skalā. Taksonu nosaukumi kodē izolēšanas valsti, numuru un laiku. 


\section{DISKUSIJA}

\subsection{Pētījuma pamatgrupa}

Šajā pētījumā tika prospektīvi iekḷauti Latvijas vien̄̄gās terciārā līmeņa bērnu slimnīcas, BKUS, populācija ar dziḷāko elpcel̦u infekciju atbilstoši PVO gadījuma defin̄īcijai. Pētījumā tika iekḷauti tikai iepriekš veseli bērni ar vecuma kritēriju 2-24 mēnešiem. Tam bija vairāki iemesli: (1) praktiski visi bērni, kas vecāki par diviem gadiem, ir vismaz vienreiz pārslimojuši HRSV; (2) bērniem, kas jaunāki par diviem mēnešiem, un pacienti ar hroniskām pavadošām slimībām elpošanas darbu būtiski ietekmē vairāki faktori. Neiznestība, iedzimta sirdskaite un hroniska elpceļu saslimšana ir būtiski HRSV infekcijas morbiditātes un mortalitātes riska faktori [Simões and Carbonell-Estrany, 2003], tomēr absolūti lielākā dal̦a zīdaiņu ar HRSV infekciju ir bijuši iepriekš veseli („HRSV naivi”), un kontroles pasākumu ieviešanai būtu jābūt primāri vērstai tieši uz šīs grupas pirmreizēju saskari ar HRSV [Anderson et al., 2013; Hall et al., 2009].

\subsection{HRSV diagnostika}

Pētījuma vajadzībām tika izstrādāta jauna klīnisko paraugu savākšanas metode virusoloǵiskajām analīzēm BKUS - NFA, kas var palielināt testa jutību pat par 30\%, salīdzinot ar deguna iztriepi [Macfarlane et al., 2005].

Šajā pētījumā izstrādātais RT-PCR diagnostikas protokols l̦auj ne tikai precīzi diagnosticēt HRSV infekciju klīniskajos paraugos, bet ir arī êrti izmantojams ātrai HRSV grupu diferencēšanai. Galvenā RT-PCR priekšrocība, salīdzinot ar imūnfluorescences testu (BKUS pētījuma laikā standarta 
virusologiiskās diagnostikas metode), ir spēja diagnosticēt vīrusa nukleīnskābes klātbūtni arī ļoti zemā koncentrācijā, kā arī detektēt replicēties nespējīgu vīrusu.

HRSV epidemiologija Eiropas valstīs ir samērā konstanta. Hospitalizētiem bērniem zem divu gadu vecuma ar dziḷāko elpceļu infekciju, HRSV ir ierosinātājs 42-45\% gadījumu [Simões and Carbonell-Estrany, 2003]. Šì pētìjuma populācijā rezultāti bija līdzịgi - HRSV izraisīja 42,5\% dziḷāko elpceļu infekciju.

\subsection{HRSV sezonalitāte}

HRSV sezonālā aktivitāte Latvijā konstanti sākās vēlāk ziemā un ieilga pavasarī (janvāris - aprīlis), salīdzinot ar vidējo sezonālo aktivitāti (decembris - februāris) ziemel̦u puslodē [Bloom-Feshbach et al., 2013], bet bija līdzīga novērojumiem Krievijā [Tatochenko et al., 2010] un bienālajām „vēlajām” sezonām, kas aprakstîtas vairākās Eiropas valstīs - Zviedrijā, Somijā, Vācijā, Šveicē, Austrijā un Horvātijā [Mlinaric-Galinovic et al., 2012; Reyes et al., 1997]. Ģeogrāfiskās HRSV sezonalitātes atškirīibas nav labi izskaidrotas, bet, domājams, ir saistîtas ar lokāliem klimatiskajiem un cilvēku sociālikulturālajiem aspektiem [Stensballe et al., 2003].

Šì pētījuma (88 HRSV pozitīvi paraugi) un Slimību profilakses un kontroles centra (SPKC) 2009.-2012. sezonu kumulatīvo datu (1297 HRSV pozitīvi paraugi; http://www.spkc.gov.lv/) salīdzinājums ir dots 4.1. attēlā. 


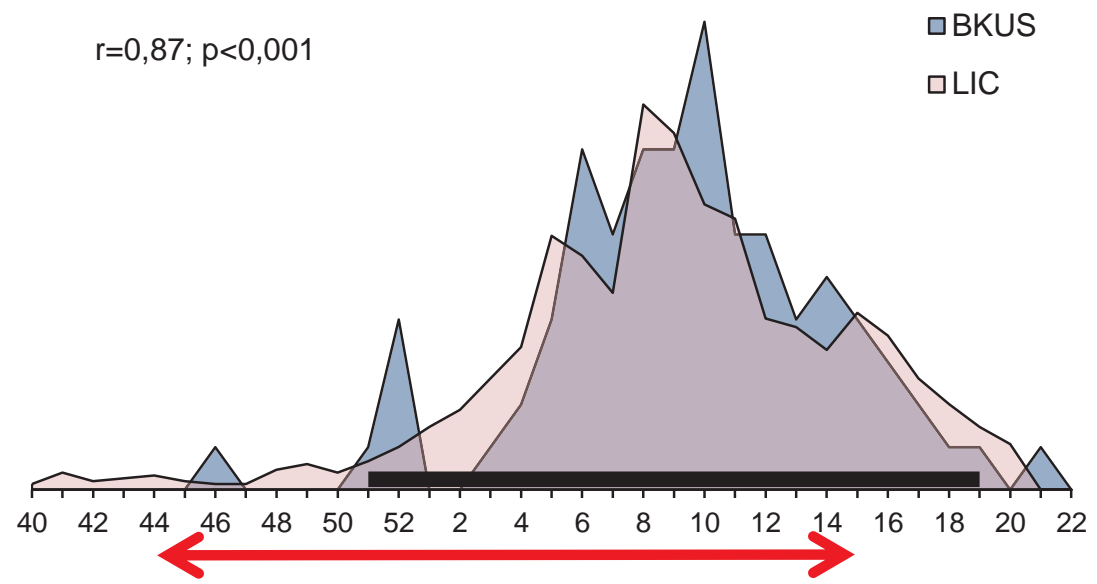

\section{1. att. Sezonalitātes datu salīdzinājums ar Slimību profilakses un kontroles centra} datiem

Normalizētas novēroto datu histogrammas attēlo relatīvos HRSV pozitīvo paraugu sadalījumu blīvumus vienā skalā. Uz $x$ ass attēlotas gada nedēḷas. LIC - SIA „Rīgas Austrumu klīniskā universitātes slimnīca” stacionāra „Latvijas Infektoloǵijas centrs” laboratorijas dati; BKUS - šī pētījuma dati. Ar biezo melno līniju norādīts kopējais HRSV epidemiologiskās aktivitātes periods trīs sezonu laikā šajā pētījumā (51. - 19. nedēḷa). Ar sarkano bultu norādīts efektīvais palivizumaba profilakses periods, ja tā aplikācija ir balstīta uz pašreizèjām ASV vadlīnijām, pieņemot, ka tā efekts ilgst 45 dienas pēc pēdējās injekcijas [American Academy of Pediatrics Committee on Infectious Diseases, 2009; Panozzo et al., 2010].

Pacientu skaita sadalījums pa nedēlāam starp šīm divām datu kopām labi korelēja $(\mathrm{r}=0,87 ; \mathrm{p}<0,001)$. Pēc SPKC datiem atsevišķi HRSV pozitīvi paraugi tiek detektēti jau sākot no 40. nedēḷas, tomēr pamatā aktivitāte (-2SD līdz +2SD) bija līdzīgā kā šajā pētîjumā - no 50. līdz 20. nedēlaiai. HRSV sezonas garums 21 nedēla atbilst globālajiem datiem [Bloom-Feshbach et al., 2013].

\subsection{HRSV klīnisko pazīmju raksturojums}

Sezonas laikā HRSV izraisīja vairāk kā $90 \%$ bronhiolītu un $50 \%$ pneimoniju, kas vēlreiz pasvītro šī patogēna lielo nozīmību agrīnu vecuma bērnu morbiditātē. Salīdzinot ar „ne-HRSV” dziḷāko elpceḷu infekciju, HRSV 
inficētie pacienti bija jaunāki, viņiem retāk bija SIRS, bet biežāk atopiskas slimības ǵimenes anamnēzē. Ir vairākas hipotēzes, kas izskaidro, kāpēc pirmajos dzīves mēnešos bērniem ir paaugstināts risks smagai HRSV izraisītai dziļāko elpceļu infekcijai: (i) imūnie mehānismi (imūnkompleksu veidošanās plaušās, zems sekretorā IgA līmenis; šūnu mediēta IV tipa imūnā reakcija plaušās; T-šūnu neatkarīgie mehānismi u.c.); (ii) fizioloǵiskie mehānismi (šauri elpceḷi, kuros neliela obstrukcija rada lielākas proporcionālās izmaiņas elpceḷu šķērsgriezuma laukumā) [Sommer et al., 2011]. No vienas puses, pēc smagas HRSV infekcijas bieži novērojamas atkārtotas sēkšanas epizodes un astma, no otras - HRSV infekcijas smagāk izpaužas atopiskiem bērniem. SIRS sindroms „ne-HRSV” grupā bija biežāk, jo, iespējams, tajā ietilpa arī bakteriālas dabas dzil̦āko elpcel̦u infekcijas.

\subsection{HRSV grupu un genotipu klīniskais salīdzinājums}

HRSV-pozitīvie paraugi tika analizēti ar HRSV-A un B specifiskiem praimeriem, bet metodes specifiskums tika pārbaudīts ar paraugu sekvenēšanu, kas visos gadījumos atbilda noteiktajai grupai. Abu grupu vīrusi cirkulēja paralēli visās trijās analizētajās sezonās. HRSV-A celmi tika izolēti biežāk, un tie dominēja pirmajās divās pētījuma sezonās. Dažādas grupu cirkulācijas īpatnības ir aprakstītas, tomēr kopumā tās seko noteiktam modelim, kur 1-3 secīgas HRSV-A dominantās sezonas nomaina viena HRSV-B dominanta sezona [Venter et al., 2001; Zlateva et al., 2007]. Iemesls šādai alternējošai cirkulācijai nav līdz galam skaidrs, matemātiski modelējot to var izskaidrot ar zemāku saimniekorganisma uzn̦ēmību pret homologu celmu reinfekciju kā pret heterologu [Sande et al., 2013; White et al., 2005]. 
3.2. tabulā dots HRSV-A un B infekciju klīniskais salīdzinājums, bet tā kā 97,7\% izolātu piederēja piederēja diviem dominantajiem genotipiem, NA1 un BA-IV, tad būtībā ir salīdzināti šie divi genotipi (izņemot ON1 no kopējās analīzes, rezultāti būtiski nemainījās). Lai analizētu šo genotipu klīnisko nozīmību, kā primārais iznākums tika ņemts hospitalizācijas ilgums, bet KSS kā slimības smaguma mērījums. Nevienā no šiem parametriem abas grupas neatšķīrās, tādējādi tika noraidīta darba 2. hipotēze. Iespējams, šajā pētījumā statistiski ticamas atšķirības starp grupām (un genotipiem) netika atrastas, jo tika iekḷauti tikai hospitalizēti pacienti, tādējādi izslēdzot no analīzes mazāk akūtus pacientus.

\subsection{HRSV celmu molekulārā analīze}

HVR2 ir ideāli piemērots molekulārās epidemioloǵijas pētījumiem, jo tā mainība salīdzinoši nelielā genoma fragmentā (mazāk kā 2\% no kopējās genoma sekvences) ataino kopējo vīrusa mainību [Rebuffo-Scheer et al., 2011; Tan et al., 2012]. Visas unikālās analizēto paraugu sekvences tika reǵistrētas GenBank datu bāzē. Katrā grupā tika noteikts viens genotips, NA1 grupā A un BA-IV grupā B, kas dominēja visu trīs sezonu laikā. L,oti līdzīgs genotipu sadalījums tika novērots līdzīgos pētījumos citās valstīs (4.2. attēls). Tādējādi netika noraidīta darba 1 . hipotēze. 
HRSV-A $(\mathrm{N}=1160)$

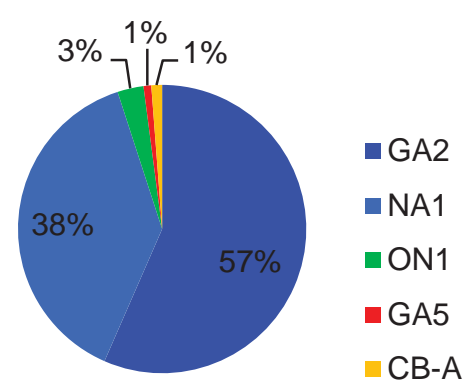

HRSV-B $(\mathrm{N}=734)$

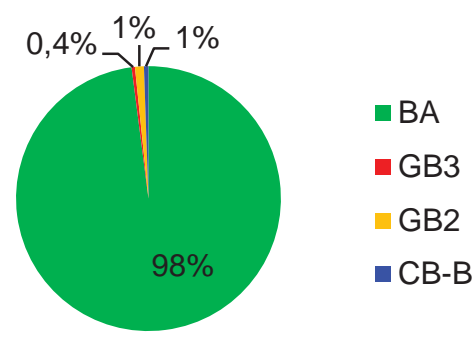

\section{2. att. Globālā HRSV genotipu izplatība 2009.-2012. sezonās}

18 (ieskaitot šo) pētījumu datu apkopojums - genotipu proporcijas grupu ietvaros, izteiktas procentos. Genotipi GA2 un NA1 vairākos pētījumos netika atsevišķi izdalīti, tādēḷ abi attēloti vienā krāsā

NA1 genotips pirmo reizi tika aprakstīts Japānā 2004./2005. sezonā [Shobugawa et al., 2009], un turpmākajos gados vairākos HRSV molekulārās epidemiologijas pētījumos tas noteikts kā dominējošais HRSV-A genotips (skat. 4.2. attēlu). NA1 genotips ir ǵenētiski tuvs GA2 genotipam un netiek viennozīmīgi atsevišķi izdalīts [van Niekerk and Venter, 2011; Yoshida et al., 2012]. Genotips GA5 Latvijā netika konstatēts, lai arī ir zināms, ka tas bija sastopams citās valstīs šajā laika periodā [Baek et al., 2012; Eshaghi et al., 2012; Houspie et al., 2013; Khor et al., 2013].

Visām HRSV-B sekvencēm tika konstatēta 60 nt duplikācija G gēnā, kas raksturo BA ǵenētisko līniju [Trento et al., 2003]. Celmi ar šo mutāciju pirmo reizi tika aprakstīti 1999. gadā Buenosairesā (no turienes saīsinājums „BA”). Nākamo 3-4 gadu laikā šādi celmi tika konstatēti visos kontinentos [Trento et al., 2010]. Kopš 2005. gada BA-IV ir visbiežāk izolētais HRSV-B genotips pasaulē, kas lielā mērā aizstājis visas pārējās HRSV-B genētiskās līnijas 
[Agrawal et al., 2009; Houspie et al., 2013; van Niekerk and Venter, 2011; Trento et al., 2010].

2012. gadā, nākamajā sezonā pēc sākotnējā apraksta, tika izolēts cits HRSV-A genotips - ON1. Genotipam ON1 raksturīga 72 nt duplikācija G gēnā 3' daḷā. Šis celms parādījās Kanādā 2010./2011. sezonā, kad tas sastādīja 10\% no visiem HRSV-A izolātiem [Eshaghi et al., 2012]. Līdzīga izplatība tika novērota arī nākamajā sezonā Vācijā (10\%) [Prifert et al., 2013], 2012./2013. sezonā Ķīnā (30\%) [Cui et al., 2013] un Japānā (13,4\%) [Tsukagoshi et al., 2013]. 2011./2012. sezonā šajā pētījumā tika detektēti tikai desmit HRSV-A vīrusi, no kuriem divi (20\%) bija ON1.

Starp Latvijas izolātiem tika novērots būtisks $G$ proteīna garuma polimorfisms - no 297 līdz 321 aa (skat. 3.5. attēlu). To ietekmēja sekojoši faktori: (i) visiem NA1 celmiem bija priekšlaicīgs terminācijas kodons un to paredzamā G proteīna sekvence bija 297 aa; (ii) vienīgajam ON1 celmam bija 321 aa gara G proteīna sekvence 24 aa insercijas dēḷ; (iii) BA-IV celmiem paredzamie G proteīna garumi bija 310 un 317 aa alternatīvu terminācijas kodonu izmantošanas dēlı. HRSV-B celmiem ir aprakstīta dažādu atgriezenisku terminācijas kodonu izmantošana, ieskaitot Stop313 $\rightarrow Q$ [Botosso et al., 2009]. In vitro, G proteīna izmēra redukcija ar „rāmja” priekšlaicīgiem terminācijas kodoniem l̦auj vīrusam izvairīties no neitralizācijas ar monoklonālajām antivielām, neizmainot tā infekciozitāti [Rueda et al., 1991].

Glikozilācija ir būtisks HRSV antigenitātes faktors, jo tā var gan nomākt, gan pastiprināt antivielu afinitāti [Botosso et al., 2009]. Celmu specifiskās monoklonālās antivielas reaǵē tikai ar glikozilētu G proteīnu [Martinez et al., 1997]. Mutācijas, kas radīja tiešu glikozilācijas receptoru nomaiņu vai samazināja to glikozilācijas iespējamību, bija bieži sastopamas, tādējādi palielinot celmu fenotipisko dažādību. Tomēr, neskatoties uz G proteīna dažādību un garuma polimorfismu, kopējā prolīna/serīna/treonīna 
proporcija bija stabila (aptuveni 10, 10 un 25\%), saglabājot mucīnam līdzīgās īpašības [Julenius et al., 2005].

Mucīnam līdzīgie reǵioni ir negatīvas RNS saturošo vīrusu bieži izmantots patogenitātes faktors, kuriem raksturīga īpaši ātra evolūcija, saglabājot to funkciju un patogenitāti. Pastāv divas hipotēzes, kas šo fenomenu izskaidro: (i) spēcīgs pozitīvās selekcijas spiediens un (ii) attīrošās selekcijas trūkums [Wertheim and Worobey, 2009]. Iepriekš veiktos pētījumos imunoloğiskās atbildes radīts selekcijas spiediens ir atrasts kā viens no būtiskiem faktoriem, kas virza HRSV genētisko mainību [Cane and Pringle, 1995], tādēl tika veikta arī padziļināta dabīgās atlases analīze. Lai arī kopējā $d N / d S$ attiecība NA1 celmiem bija $>1$, kas liecina par evolucionāru selekciju, tikai divas pozīcijas atradās zem pozitīvas selekcijas spiediena. Abas šīs vietas ir iesaistîtas celma A2 B un T šūnu epitopos [Cane, 1997; Hancock et al., 2003; Norrby et al., 1987]. Šī atradne nav konsekventa dažādos pētījumos, piemēram, M262 un N273 tika arī prognozēti [Eshaghi et al., 2012; Houspie et al., 2013; Kushibuchi et al., 2013; Yoshida et al., 2012; Zlateva et al., 2004], bet netika apstiprināti [Botosso et al., 2009; Tan et al., 2012], lietojot līdzīgu metodoloǵiju kā šajā pētījumā. BA-IV celmiem bija vērojama lielāka dažādība, ko mazāk ietekmēja pozitīvās selekcijas spiediens - kopējā $d N / d S$ attiecība bija 0,45. Divi pozitīvi selekcionētie kodoni, L219 un T270, ir iepriekš ziṇoti [Botosso et al., 2009; Kushibuchi et al., 2013; Zlateva et al., 2005], kamēr citi kodoni (142, 227, 235, 258, 259, 311), kas šajos pašos pētījumos izrādījās zem pozitīvās selekcijas spiediena, bija konservatīvi Latvijas sekvencēs. Šāds konsekvences trūkums skaidrojams ar vairākiem faktoriem. Šajā pētījuma tika analizēts tikai viens genotips katrā HRSV grupā. Citos pētījumos, kuros novērojumi veikti pat 10 un vairāk gadus, tika iekḷauti citi tobrīd aktīvi cirkulējoši genotipi, kā arī šobrīd jau izmirušas ǵenētiskās līnijas. Šādas atšksirības varētu arī rasties celmiem adaptējoties dažādu saimnieka organismu 
populāciju imunitātes līmeņiem. Visbeidzot, tas var norādīt arī uz pozitīvās selekcijas trūkumu un vīrusa evolucionēšanu atslābinātas attīrošās selekcijas apstākḷlos, t.i. HVR2 segments, saglabājot mucīnam līdzīgās īpašības, nav pārāk ierobežots savā mainībā [Wertheim and Worobey, 2009].

\subsection{HRSV celmu globālā diseminācija}

Kopš sākotnējā apraksta Kanādā, ON1 celmi ir izolēti vairākās pasaules vietās. Priferta ar kolēgiem konstatēja asociāciju starp šo genotipu un stacionēšanu intensīvās terapijas nodaḷā [Prifert et al., 2013]. Tomēr šī asociācija pagaidām nav citur validēta. Šajā pētījumā ON1 pacientiem bija vidēji smaga dzil̦āko elpcel̦u infekcija un viņiem nebija nepieciešama stacionēšana intensīvās terapijas nodal̦ā. Ešagī ar kolēǵiem izvirzīja hipotēzi, ka 72 nt duplikācija radusies, RNS polimerāzei pārlecot atpakalı, vietā, kur atrodas 7 nt atkārtojums un sekundārās RNS struktūras cilpa [Eshaghi et al., 2012]. Tā ir šobrīe lielākā aprakstītā dabīgā insercija G gēnā. Šādas mutācijas ir iespējams izmantot kā „dabīgu marķieri”, lai rekonstruētu HRSV celmu disemināciju [Trento et al., 2010].

Šajā pētījumā ir pirmo reizi aprēķināts ON1 evolūcijas ātrums, populācijas dinamika un diskrētā filoǵeogrāfiskā analīze, balstoties uz pasaulē izdalītajām sekvencēm laika periodā no 2010. gada decembra līdz 2013. gada jūnijam. Aprēķinātais ON1 evolūcijas ātrums HVR2 segmentā $\left(7,92 \times 10^{-3}\right.$ nt/pozīcijā/gadā) bija ievērojami lielāks par citu HRSV-A un B genotipu evolūciju HVR2 segmentā $\left(3,6-4,7 \times 10^{-3}\right)$ [Kushibuchi et al., 2013; Tan et al., 2012]. Tas, iespējams, liecina par atslābinātu attīrošo selekcijas spiedienu, kas darbojas duplicētajā reǵionā [Wertheim and Worobey, 2009]. 
ON1 demogrāfiskā vēsture līdz šim ir bijusi ievērojami savādāka kā BA genotipam, kam pēc 60 nt duplikācijas G gēnā pirmajos desmit gados bija vērojama populācijas izplešanās [Trento et al., 2010]. Efektīvās ON1 populācijas izmērs pirms 2012./2013. sezonas sākuma samazinājās, bet šie dati var mainīties, kad kḷūs pieejamas jaunas sekvences. Iespējams, ka tāpat kā BA genotipiem, papildus duplikācijai ir nepieciešamas citas mutācijas, lai panāktu optimālu vīrusa adaptāciju replikācijai. Jaunajam genotipam varētu rasties imunoloǵiskas priekšrocības, jo ON1 duplicētais reǵions satur vairākus B un T šūnu epitopus [Cane, 1997] un tas maina G proteīna $O$ - un $N$-glikozilācijas īpašības.

Diskrētā filoǵeogrāfiskā analīze uzrādīja divas galvenās ON1 transmisijas likumsakarības: (i) viļ̣nveidīga izplatīšanās no Kanādas caur Itāliju uz pārējām pasaules valstīm ar noteiktu virzienu no rietumiem uz austrumiem un (ii) gravitācijas efekts, kur, domājams, sekojot cilvēku pārvietošanās maršrutiem, vīruss no vairākām valstīm atkārtoti nonāca Vācijā [Holmes et al., 2008]. ON1 izplatības rekonstrukcijā vairākām lokalizācijas pārejām trūka statistiskā nozīmība, tomēr šo hipotēzi atbalsta vairāki papildus pierādījumi. Pirmkārt, visiem ON1 genomiem, kas pieejami GenBank, ir arī E232 $\rightarrow G$ un $T 253 \rightarrow K$ mutācijas; $E 232 \rightarrow G$ bija aprakstīta vienam no Kanādas NA1 celmiem, kas tika izolēts vienā pētījumā ar ON1, bet nav raksturīga citiem NA1 celmiem. Otrkārt, cits NA1 celms (LV/043/12) arī tika izolēts Kanādā un nākamajā sezonā Itālijā, Vācijā un Latvijā. Treškārt, aprēķinātais tMRCA (2010. gada augusts) labi sakrīt ar Ešagī un kolēǵu prognozēm, ka šis genotips ir radies dažus mēnešus pirms 2010./2011. ziemas [Eshaghi et al., 2012]. Kopumā netika noraidīta darba 3. hipotēze, jo ticami tika rekonstruēta genotipa ON1 globālā izplatība. 


\section{SECINĀJUMI}

1. Pētījuma vajadzībām tika izstrādāta oriǵināla HRSV PCR diagnostikas metode, kas ḷāva izšķirt arī galvenās grupas HRSV-A un B un, salīdzinot ar IFA testu, uzrādīja 95,2\% jutību un 91,2\% specifiskumu.

2. Ar dziḷāko elpceḷu infekcijām stacionētiem bērniem vecumā no 2-24 mēnešiem HRSV bija ierosinātājs 42,5\% gadījumu.

3. HRSV sezonālā aktivitāte tika noteikta no 51. līdz 19. gada nedēlaiai.

4. Pētījumā netika noteikta saistība starp HRSV ǵenētisko grupu A un B vai atsevišķ genotipu un to izraisīto infekciju klīnisko smagumu (noraidīta darba 2. hipotēze).

5. Pētījumā tika detektēti vairāki gan iepriekš citur izolēti, gan Latvijai unikāli HRSV celmi, kuru molekulārā epidemiologija kopumā atbilda globālajām cirkulācijas tendencēm (netika noraidīta darba 1. hipotēze). Glikoproteīna G mainību varēja tikai dal̦ēji izskaidrot ar saimniekorganisma imunoloǵiskās sistēmas radītu selekcijas spiedienu.

6. Pielietojot molekulārā pulksteņa principu Baijesa evolucionārajā analīzē, ticami tika rekonstruēta genotipa ON1 globālā izplatība un populācijas dinamika (netika noraidīta darba 3. hipotēze). 


\section{PRAKTISKĀS REKOMENDĀCIJAS}

1. N̦emot vērā biežo izplatību stacionētiem bērniem ar dziḷāko elpceḷu infekciju tā sezonas laikā, optimālai pacientu kohortēšanai būtu vēlams ieviest HRSV ātrās diagnostikas testu terciārā līmen̦a bērnu slimnīcā. Tas, iespējams, l̦autu ietaupīt arī HRSV infekciju ārstēšanā nepieciešamos resursus.

2. Valsts specifiskās imūnprofilakses stratēǵijas veidošanā būtu jāņem vērā, ka Latvijā HRSV sezonālā aktivitāte sākas un beidzas vēlāk kā citās Ziemeļu puslodes valstīs un šo valstu rekomendācijas var nederēt Latvijas apstākḷiem. 


\section{AUTORA PUBLIKĀCIJAS}

1. Balmaks R, Ribakova I, Gardovska D, Kazaks A. 2013. Molecular epidemiology of human respiratory syncytial virus over three consecutive seasons in Latvia. Journal of Medical Virology doi:10.1002/jmv.23855.

2. Balmaks R, Ribakova I, Gardovska D, Kazaks A. 2013. Molecular epidemiology of respiratory syncytial virus during the 2009-2010 season in Latvia. Archives of Virology 158(5):1089-1092.

3. Eihvalde L, Ansone S, Balmaks R, Ribakova I, Kazāks A, Grope I, Kozlovska L, Livdāne J, Gardovska D. 2012. Viral lower respiratory tract infections in children under 2 years of age in the winter season of 2010/2011 in Children's University Hospital, Riga (Latvia). Lietuvos Bendrosios Praktikos Gydytojas 16(9):612-617.

4. Balmaks R, Kazaks A, Likopa Z, Grope I, Rasnacs O, Gardovska D. 2011. A new tool for molecular monitoring of respiratory syncytial virus in children with lower respiratory tract infections. Riga Stradins University Collection of Scientific Papers 2010:100-105. 


\section{IZMANTOTĀ LITERATŪRA}

1. Agrawal AS, Sarkar M, Ghosh S et a. 2009. Prevalence of respiratory syncytial virus group B genotype BA-IV strains among children with acute respiratory tract infection in Kolkata, Eastern India. Journal of Clinical Virology 45(4):358-361.

2. American Academy of Pediatrics Committee on Infectious Diseases. 2009. Modified recommendations for use of palivizumab for prevention of respiratory syncytial virus infections. Pediatrics 124(6):1694-1701.

3. American Academy of Pediatrics Subcommittee on Diagnosis and Management of Bronchiolitis. 2006. Diagnosis and management of bronchiolitis. Pediatrics 118(4):1774-1793.

4. Anderson LJ, Dormitzer PR, Nokes DJ, Rappuoli R, Roca A, Graham BS. 2013. Strategic priorities for respiratory syncytial virus (RSV) vaccine development. Vaccine 31, Supplement 2(0):B209-B215.

5. Baek Y, Choi E, Song M-S et al. Prevalence and genetic characterization of respiratory syncytial virus (RSV) in hospitalized children in Korea. Archives of Virology 157(6):1039-1050.

6. Bielejec F, Rambaut A, Suchard MA, Lemey P. 2011. SPREAD: spatial phylogenetic reconstruction of evolutionary dynamics. Bioinformatics 27(20):2910-2912.

7. Bloom-Feshbach K, Alonso WJ et al. 2013. Latitudinal variations in seasonal activity of influenza and respiratory syncytial virus (RSV): a global comparative review. PLoS ONE 8(2):e54445.

8. Botosso VF, Zanotto PMdA, Ueda M et al. 2009. Positive selection results in frequent reversible amino acid replacements in the $G$ protein sene of human respiratory syncytial virus. PLoS Pathog 5(1):e1000254.

9. Cane PA. 1997. Analysis of linear epitopes recognised by the primary human antibody response to a variable region of the attachment $(G)$ protein of respiratory syncytial virus. Journal of Medical Virology 51(4):297-304.

10. Cane PA, Pringle CR. 1995. Evolution of subgroup A respiratory syncytial virus: evidence for progressive accumulation of amino acid changes in the attachment protein. Journal of Virology 69(5):2918-2925.

11. Collins P, Crowe J. 2007. Respiratory syncytial virus and metapneumovirus. In: Knipe D, Howley P, editors. Fields virology. 5th ed. Philadelphia: Lippincott Williams \& Wilkins. p 1602-1646.

12. Collins PL, Melero JA. 2011. Progress in understanding and controlling respiratory syncytial virus: Still crazy after all these years. Virus Research 162(12):80-99. 
13. Cui G, Qian Y, Zhu R et al. 2013. Emerging human respiratory syncytial virus genotypeON1 found in infants with pneumonia in Beijing, China. Emerging Microbes and Infections 2(4):e22.

14. Delport W, Poon AFY, Frost SDW, Kosakovsky Pond SL. 2010. Datamonkey 2010: a suite of phylogenetic analysis tools for evolutionary biology. Bioinformatics 26(19):2455-2457.

15. Drummond AJ, Suchard MA, Xie D, Rambaut A. 2012. Bayesian phylogenetics with BEAUti and the BEAST 1.7. Molecular Biology and Evolution 29(8):19691973.

16. Eshaghi A, Duvvuri VR, Lai R et al. 2012. Genetic variability of human respiratory syncytial virus A strains circulating in Ontario: A novel genotype with a 72 nucleotide G gene duplication. PLoS ONE 7(3):e32807.

17. Falsey AR, Hennessey PA, Formica MA, Cox C, Walsh EE. 2005. Respiratory syncytial virus infection in elderly and high-risk adults. New England Journal of Medicine 352(17):1749-1759.

18. Frost SDW, Volz EM. 2010. Viral phylodynamics and the search for an 'effective number of infections'. Philosophical Transactions of the Royal Society B: Biological Sciences 365(1548):1879-1890.

19. Glezen W, Taber L, Frank A, Kasel J. 1986. Risk of primary infection and reinfection with respiratory syncytial virus. American Journal of Diseases of Children 140(6):543-546.

20. Gupta R, Jung E, Brunak S. 2004. Prediction of N-glycosylation sites in human proteins. http://www.cbs.dtu.dk/services/NetNGlyc/.

21. Goldstein B, Giroir B, Randolph A, Sepsis MotICCoP. 2005. International pediatric sepsis consensus conference: Definitions for sepsis and organ dysfunction in pediatrics. Pediatric Critical Care Medicine 6(1):2-8.

22. Hall CB, Weinberg GA, Iwane MK et al. 2009. The burden of respiratory syncytial virus Infection in young children. New England Journal of Medicine 360(6):588-598.

23. Hancock GE, Tebbey PW, Scheuer CA, Pryharski KS, Heers KM, LaPierre NA. 2003. Immune responses to the nonglycosylated ectodomain of respiratory syncytial virus attachment glycoprotein mediate pulmonary eosinophilia in inbred strains of mice with different MHC haplotypes. Journal of Medical Virology 70(2):301-308.

24. Hart GW. 1992. Glycosylation. Current Opinion in Cell Biology 4(6):1017-1023.

25. Henderson FW, Collier AM, Clyde WA, Denny FW. 1979. Respiratory-syncytialvirus infections, reinfections and immunity. New England Journal of Medicine 300(10):530-534.

26. Holmes E. 2008. Evolutionary history and phylogeography of human viruses. Annual Review of Microbiology 62:307-328. 
27. Hornsleth A, Klug B, Nir M, Johansen J, Hansen K, Christensen L, Larsen LB. 1998. Severity of respiratory syncytial virus disease related to type and genotype of virus and to cytokine values in nasopharyngeal secretions. The Pediatric Infectious Disease Journal 17(12):1114-1121.

28. Houspie L, Lemey P, Keyaerts E et al. 2013. Circulation of HRSV in Belgium: from multiple genotype circulation to prolonged circulation of predominant genotypes. PLoS ONE 8(4):e60416.

29. Imaz MS, Sequeira MD, Videla C, Veronessi I, Cociglio R, Zerbini E, Carballal G. 2000. Clinical and epidemiologic characteristics of respiratory syncytial virus subgroups A and B infections in Santa Fe, Argentina. Journal of Medical Virology 61(1):76-80.

30. Jafri HS, Wu X, Makari D, Henrickson KJ. 2013. Distribution of respiratory syncytial virus subtypes A and B among infants presenting to the emergency department with lower respiratory tract Infection or apnea. The Pediatric Infectious Disease Journal 32(4):335-340.

31. Johnson LW, Robles J, Hudgins A, Osburn S, Martin D, Thompson A. 2013. Management of bronchiolitis in the emergency department: impact of evidencebased guidelines? Pediatrics 131(Supplement 1):S103-S109.

32. Johnson PR, Spriggs MK, Olmsted RA, Collins PL. 1987. The G glycoprotein of human respiratory syncytial viruses of subgroups A and B: extensive sequence divergence between antigenically related proteins. Proceedings of the National Academy of Sciences 84(16):5625-5629.

33. Julenius K, Mølgaard A, Gupta R, Brunak S. 2005. Prediction, conservation analysis, and structural characterization of mammalian mucin-type Oglycosylation sites. Glycobiology 15(2):153-164.

34. Katzov-Eckert H, Botosso V, Neto E, Zanotto P, VGND consortium. 2012. Phylodynamics and dispersal of HRSV entails its permanence in the general population in between yearly outbreaks in children. PLoS One 7(10):e41953.

35. Khor C-S, Sam IC, Hooi P-S, Chan Y-F. 2013. Displacement of predominant respiratory syncytial virus genotypes in Malaysia between 1989 and 2011. Infection, Genetics and Evolution 14(0):357-360.

36. Kneyber M, Brandenburg A, Rothbarth P, de Groot R, Ott A, van Steensel-Moll H. 1996. Relationship between clinical severity of respiratory syncytial virus infection and subtype. Archives of Disease in Childhood 75(2):137-140.

37. Kosakovsky Pond SL, Frost SDW, Muse SV. 2005. HyPhy: hypothesis testing using phylogenies. Bioinformatics 21(5):676-679.

38. Kushibuchi I, Kobayashi M, Kusaka T et al. Molecular evolution of attachment glycoprotein $(\mathrm{G})$ gene in human respiratory syncytial virus detected in Japan 2008-2011. Infection, Genetics and Evolution 18(0):168-173. 
39. Larkin MA, Blackshields G, Brown NP et al. 2007. Clustal W and Clustal X version 2.0. Bioinformatics 23(21):2947-2948.

40. Lee W-J, Kim Y-j, Kim D-W, Lee HS, Lee HY, Kim K. 2012. Complete genome sequence of human respiratory syncytial virus genotype A with a 72-nucleotide duplication in the attachment protein G gene. Journal of Virology 86(24):1381013811.

41. Librado P, Rozas J. 2009. DnaSP v5: a software for comprehensive analysis of DNA polymorphism data. Bioinformatics 25(11):1451-1452.

42. Lowell DI, Lister G, Von Koss H, McCarthy P. 1987. Wheezing in infants: the response to epinephrine. Pediatrics 79(6):939-945.

43. Lozano R, Naghavi M, Foreman K et al. 2012. Global and regional mortality from 235 causes of death for 20 age groups in 1990 and 2010: a systematic analysis for the Global Burden of Disease Study 2010. The Lancet 380(9859):2095-2128.

44. Macfarlane P, Denham J, Assous J, Hughes C. 2005. RSV testing in bronchiolitis: which nasal sampling method is best? Archives of Disease in Childhood 90(6):634-635.

45. Martinello RA, Chen MD, Weibel C, Kahn JS. 2002. Correlation between respiratory syncytial virus genotype and severity of illness. Journal of Infectious Diseases 186(6):839-842.

46. Martinez I, Dopazo J, Melero JA. 1997. Antigenic structure of the human respiratory syncytial virus $G$ glycoprotein and relevance of hypermutation events for the generation of antigenic variants. Journal of General Virology 78(10):24192429.

47. McIntosh E, De Silva L, Oates R. 1993. Clinical severity of respiratory syncytial virus group A and B infection in Sydney, Australia. Pediatric Infectious Disease Journal 12(10):815-819.

48. Meijboom MJ, Rozenbaum MH, Benedictus A et al. 2012. Cost-effectiveness of potential infant vaccination against respiratory syncytial virus infection in The Netherlands. Vaccine 30(31):4691-4700.

49. Mlinaric-Galinovic G, Tabain I, Kukovec T et al. 2012. Analysis of biennial outbreak pattern of respiratory syncytial virus according to subtype (A and B) in the Zagreb region. Pediatrics International 54(3):331-335.

50. Mufson MA, Örvell C, Rafnar B, Norrby E. 1985. Two distinct subtypes of human respiratory syncytial virus. Journal of General Virology 66(10):2111-2124.

51. Nair H, Nokes DJ, Gessner BD et al. 2010. Global burden of acute lower respiratory infections due to respiratory syncytial virus in young children: a systematic review and meta-analysis. The Lancet 375(9725):1545-1555.

52. Nikiforova R, Lucenko I, Zamjatina N. 2011. Pārskats par saslimstību ar akūtām augšējo elpcel̦u infekcijām (AAEI) un gripu 2010. - 2011. gada epidēmiskajā sezonā. Epidemiolog̣ijas biḷetens 34(1205):1-21. 
53. Norrby E, Mufson MA, Alexander H, Houghten RA, Lerner RA. 1987. Sitedirected serology with synthetic peptides representing the large glycoprotein $G$ of respiratory syncytial virus. Proceedings of the National Academy of Sciences 84(18):6572-6576.

54. Palomo C, García-Barreno B, Peñas C, Melero JA. 1991. The G protein of human respiratory syncytial virus: significance of carbohydrate side-chains and the Cterminal end to its antigenicity. Journal of General Virology 72(3):669-675.

55. Panozzo CA, Stockman LJ, Curns AT, Anderson LJ. 2010. Use of respiratory syncytial virus surveillance data to optimize the timing of immunoprophylaxis. Pediatrics 126(1):e116-e123.

56. Peret TCT, Hall CB, Hammond GW et al. 2000. Circulation patterns of group A and B human respiratory syncytial virus genotypes in 5 communities in North America. Journal of Infectious Diseases 181(6):1891-1896.

57. Prifert C, Streng A, Krempl C, Liese J, Weissbrich B. 2013. Novel respiratory syncytial virus a genotype, Germany, 2011-2012. Emerging Infectious Diseases 19(6):1029-1030.

58. Rebuffo-Scheer C, Bose M, He J et al. 2011. Whole genome sequencing and evolutionary analysis of human respiratory syncytial virus A and B from Milwaukee, WI 1998-2010. PLoS ONE 6(10):e25468.

59. Reyes M, Eriksson M, Bennet R, Hedlund K, Ehrnst A. 1997. Regular pattern of respiratory syncytial virus and rotavirus infections and relation to weather in Stockholm, 1984--1993. Clinical Microbiology and Infection 3(6):640-646.

60. Reynolds EOR, Cook CD. 1963. The treatment of bronchiolitis. The Journal of pediatrics 63(6):1205-1207.

61. Rueda P, Delgado T, Portela A, Melero JA, García-Barreno B. 1991. Premature stop codons in the $\mathrm{G}$ glycoprotein of human respiratory syncytial viruses resistant to neutralization by monoclonal antibodies. Journal of Virology 65(6):3374-3378.

62. Saitou N, Nei M. 1987. The neighbor-joining method: a new method for reconstructing phylogenetic trees. Molecular Biology and Evolution 4(4):406-425.

63. Sande CJ, Mutunga MN, Medley GF, Cane PA, Nokes DJ. 2013. Group- and genotype-specific neutralizing antibody responses against respiratory syncytial virus in infants and young children with severe pneumonia. Journal of Infectious Diseases 207(3):489-492.

64. Shay DK, Holman RC, Roosevelt GE, Clarke MJ, Anderson LJ. 2001. Bronchiolitis-associated mortality and estimates of respiratory syncytial virusassociated deaths among US Children, 1979-1997. Journal of Infectious Diseases 183(1):16-22.

65. Shobugawa Y, Saito R, Sano Y et al. 2009. Emerging genotypes of human respiratory syncytial virus subgroup A among patients in Japan. Journal of Clinical Microbiology 47(8):2475-2482. 
66. Simões EAF, Carbonell-Estrany X. 2003. Impact of severe disease caused by respiratory syncytial virus in children living in developed countries. The Pediatric Infectious Disease Journal 22(2):S13-S20.

67. Sommer C, Resch B, Simões EAF. 2011. Risk factors for severe respiratory syncytial virus lower respiratory tract infection. The Open Microbiology Journal 5:144-154.

68. Stensballe L, Devasundaram J, Simões E. 2003. Respiratory syncytial virus epidemics: the ups and downs of a seasonal virus. The Pediatric Infectious Disease Journal 22(2):S21-S32.

69. Sullender WM, Sun L, Anderson LJ. 1993. Analysis of respiratory syncytial virus genetic variability with amplified cDNAs. Journal of Clinical Microbiology 31(5):1224-1231.

70. Tamura K, Peterson D, Peterson N, Stecher G, Nei M, Kumar S. 2011. MEGA5: molecular evolutionary genetics analysis using maximum likelihood, evolutionary distance, and maximum parsimony methods. Molecular Biology and Evolution 28(10):2731-2739.

71. Tan L, Lemey P, Houspie L et al. 2012. Genetic variability among complete human respiratory syncytial virus subgroup A genomes: bridging molecular evolutionary dynamics and epidemiology. PLoS ONE 7(12):e51439.

72. Tatochenko V, Uchaikin V, Gorelov A et al. 2010. Epidemiology of respiratory syncytial virus in children $\leq 2$ years of age hospitalized with lower respiratory tract infections in the Russian Federation: a prospective, multicenter study. Clinical Epidemiology(2):221-227.

73. Trento A, Casas I, Calderón A et al. 2010. Ten years of global evolution of the human respiratory syncytial virus BA genotype with a 60-nucleotide duplication in the G protein gene. Journal of Virology 84(15):7500-7512.

74. Trento A, Galiano M, Videla C et al. 2003. Major changes in the G protein of human respiratory syncytial virus isolates introduced by a duplication of 60 nucleotides. Journal of General Virology 84(11):3115-3120.

75. Trento A, Viegas M, Galiano M et al. 2006. Natural history of human respiratory syncytial virus inferred from phylogenetic analysis of the attachment (G) glycoprotein with a 60-nucleotide duplication. Journal of Virology 80(2):975-984.

76. Tsukagoshi H, Yokoi H, Kobayashi M et al. 2013. Genetic analysis of attachment glycoprotein $(\mathrm{G})$ gene in new genotype ON1 of human respiratory syncytial virus detected in Japan. Microbiology and Immunology. Epub: June 11, 2013. doi: 10.1111/1348-0421.12075.

77. Valley-Omar Z, Muloiwa R, Hu N, Eley B, Hsiao N. 2013. Novel respiratory syncytial virus subtype ON1 among children, Cape Town, South Africa, 2012. Emerging Infectious Diseases 19(4):668-670. 
78. van Niekerk S, Venter M. 2011. Replacement of previously circulating respiratory syncytial virus subtype B strains with the BA genotype in South Africa. Journal of Virology 85(17):8789-8797.

79. Venter M, Madhi SA, Tiemessen CT, Schoub BD. 2001. Genetic diversity and molecular epidemiology of respiratory syncytial virus over four consecutive seasons in South Africa: identification of new subgroup A and B genotypes. Journal of General Virology 82(9):2117-2124.

80. Wang E, Law B, Stephens D. 1995. Pediatric Investigators Collaborative Network on Infections in Canada (PICNIC) prospective study of risk factors and outcomes in patients hospitalized with respiratory syncytial viral lower respiratory tract infection. The Journal of Pediatrics 126(2):212-219.

81. Wang L-F, Collins PL, Fouchier RAM et al. 2012. Family Paramyxoviridae. In: King AMQ, Lefkowitz E, Adams MJ, Carstens EB, editors. Virus Taxonomy: Ninth Report of the International Committee on Taxonomy of Viruses. San Diego: Elsevier Academic Press. p 672-685.

82. Wertheim JO, Worobey M. 2009. Relaxed selection and the evolution of RNA virus mucin-like pathogenicity factors. Journal of Virology 83(9):4690-4694.

83. White L, Waris M, Cane P, Nokes D, Medley G. 2005. The transmission dynamics of groups A and B human respiratory syncytial virus (hRSV) in England \& Wales and Finland: seasonality and cross-protection. Epidemiology and Infection 133(2):279-289.

84. Wright P, Cutts F. 2000. Generic protocol to examine the incidence of lower respiratory infection due to respiratory syncytial virus in children less than five years of age: field test version. Geneva: Department of Vaccines and Other Biologicals, World Health Organization. 1-34 p.

85. Yoshida A, Kiyota N, Kobayashi M et al. 2012. Molecular epidemiology of the attachment glycoprotein $(G)$ gene in respiratory syncytial virus in children with acute respiratory infection in Japan in 2009/2010. Journal of Medical Microbiology 61(6):820-829.

86. Zhang R-F, Jin Y, Xie Z-P et al. 2010. Human respiratory syncytial virus in children with acute respiratory tract infections in China. Journal of Clinical Microbiology 48(11):4193-4199.

87. Zhang Z, Schwartz S, Wagner L, Miller W. 2000. A greedy algorithm for aligning DNA sequences. Journal of Computational Biology 7(1-2):203-2014.

88. Zlateva KT, Lemey P, Moës E, Vandamme A-M, van Ranst M. 2005. Genetic variability and molecular evolution of the human respiratory syncytial virus subgroup B attachment G protein. Journal of Virology 79(14):9157-9167.

89. Zlateva KT, Lemey P, Vandamme A-M, van Ranst M. 2004. Molecular evolution and circulation patterns of human respiratory syncytial virus subgroup A: positively selected sites in the attachment G glycoprotein. Journal of Virology 78(9):4675-4683. 
90. Zlateva KT, van Ranst M. 2004. Detection of subgroup B respiratory syncytial virus in the cerebrospinal fluid of a patient with respiratory syncytial virus Pneumonia. The Pediatric Infectious Disease Journal 23(11):1065-1066.

91. Zlateva KT, Vijgen L, Dekeersmaeker N, Naranjo C, van Ranst M. 2007. Subgroup prevalence and genotype circulation patterns of human respiratory syncytial virus in Belgium during ten successive epidemic seasons. Journal of Clinical Microbiology 45(9):3022-3030. 